Eur. J. Mineral.

2018, 30, 695-710

Published online 9 May 2018

\title{
Assessment of $O$ and $F e$ isotope heterogeneity in garnet from Kakanui (New Zealand) and Erongo (Namibia)
}

\author{
MAJa UROSEVIC ${ }^{1, *}$, Oliver NEBEL ${ }^{2}$, José AlBerto PADRÓN-NAVARTA ${ }^{1,3}$ and DANIEla RUBATTO ${ }^{1,4,5}$ \\ ${ }^{1}$ Research School of Earth Sciences, The Australian National University, 2601 Acton, ACT, Australia \\ *Corresponding author, e-mail: majice_2002@yahoo.es \\ ${ }^{2}$ School of Earth, Atmosphere and Environment, Monash University, 3800 Clayton, VIC, Australia \\ ${ }^{3}$ Géosciences Montpellier, CNRS \& Université Montpellier, 34095 Montpellier, France \\ ${ }^{4}$ Department of Geological Sciences, University of Bern, 3012 Bern, Switzerland \\ ${ }^{5}$ Institute of Earth Sciences,University of Lausanne, 1015 Lausanne, Switzerland
}

\begin{abstract}
Oxygen and iron isotope variations have been investigated in three compositionally distinct garnet samples to assess natural variations and search for suitable reference material. We report in situ major, trace element and O isotope analyses for mantle-derived garnet xenocrysts from Kakanui, New Zealand, as well as magmatic and hydrothermal garnets (skarn) from two different localities in Erongo, Namibia. The in situ analyses are complemented by bulk mineral separate Fe isotope analyses for all samples and $\mathrm{CO}_{2}$ laser fluorination oxygen isotope analysis for Kakanui garnet. Mantle-derived pyrope-rich garnet megacrysts from Kakanui are chemically homogeneous in major and trace elements, and in $\mathrm{O}$ isotopes, $\left(\delta^{18} \mathrm{O}_{\text {VSMOW }}=5.67 \pm 0.02 \%\right.$ ) . Magmatic garnet from Erongo, Namibia, is rich in $\mathrm{Mn}$ and $\mathrm{Fe}^{2+}$ and very poor in Ca showing minor variations along the almandine-spessartine join $\left[\left(\mathrm{Fe}_{2} \mathrm{Mn}_{3} \mathrm{Al}_{2} \mathrm{Si} \mathrm{O}_{3} \mathrm{O}_{12}\right]\right.$. Although rare earth elements vary over one order of magnitude, no resolvable $\mathrm{O}$ isotope zoning is observed $\left(\delta^{18} \mathrm{O}=9.3 \pm 0.3 \%, 1 \sigma\right)$. Hydrothermal garnet from Namibia is rich in $\mathrm{Ca}$ and $\mathrm{Fe}^{3+}$ and shows strong zonation along the andradite-grossular join $\left[\mathrm{Ca}_{3}\left(\mathrm{Fe}^{3+}\right.\right.$, $\mathrm{Al})_{2} \mathrm{Si}_{3} \mathrm{O}_{12}$ ] with a considerable spread in trace-element contents, accompanied by a limited, but resolvable, spread in $\mathrm{O}$ isotopes values between cores $(8.3 \pm 0.3 \%, 1 \sigma)$ and rims $(7.4 \pm 0.3 \%, 1 \sigma)$. Iron isotopes (expressed as $\left.\delta^{57} \mathrm{Fe}_{\text {IRMM-014 }}\right)$ within bulk garnet separates are heterogeneous in both crustal garnet from Erongo with a large spread ranging from -0.15 to $+0.30 \%$ in igneous garnet and from +0.4 to $+1.1 \%$ in hydrothermal garnet. Igneous garnet from Kakanui are homogeneous with an average $\delta^{57} \mathrm{Fe}_{\text {IRMM- } 014}$ of $+0.09 \pm 0.01,1 \sigma$. The $\mathrm{Fe}^{3+}$-dominated andradite shows very heavy Fe isotopes, suggesting a link between preferential ferric iron incorporation into garnet and $\mathrm{Fe}$ isotope signatures. Combined $\mathrm{O}$ and $\mathrm{Fe}$ isotope analyses in garnet can provide potentially important insights into the nature of parental medium from which the garnet forms (based on $\mathrm{O}$ isotopes) and associated petrogenetic processes (e.g., redox conditions based on $\mathrm{Fe}$ isotopes), though more systematic studies are required to further assess these proxies in natural systems. Finally, we propose that Kakanui garnet might represent a suitable reference material for both, $\mathrm{O}$ and $\mathrm{Fe}$ isotope analyses.
\end{abstract}

Key-words: stable isotopes; oxygen; iron; garnet; reference material.

\section{Introduction}

Garnet is a common mineral solid solution occurring in a large range of rock types in most geodynamic terrestrial environments. This omnipresent nature and large stability field renders garnet an ideal chemical reservoir for studying the formation and history of its host rock, and the crustal conditions at which it formed. From major-element analyses, it has become clear that garnet commonly exhibits chemical heterogeneity within single grains corresponding to different stages of garnet growth under changing pressure-temperate-composition $(P-T-X)$ conditions (e.g. Spear, 2014; Caddick \& Kohn, 2013). The chemical variations in major elements in these growth zones are also reflected in trace-element variations and associated radiogenic isotope variations (Hermann \& Rubatto, 2003;
Herwartz et al., 2011; Pollington \& Baxter, 2011; Dragovic et al., 2015; Schmidt et al., 2015; Raimondo et al., 2017). The large chemical diversity in garnet can extend to stable isotope variations (Snyder et al., 1995; Vielzeuf et al., 2005; Martin et al., 2014; Page et al., 2014; Rubatto \& Angiboust, 2015), which can provide additional important constraints on garnet growth mechanisms and ultimately their geotectonic history. Two elements are of particular interest: iron and oxygen. Both elements occur in garnet as major elements and have been shown to yield resolvable variations with state-of-the-art mass spectrometric techniques in high-temperature rocks and minerals (Vielzeuf et al., 2005; Williams et al., 2005, 2009; Page et al., 2010; Martin et al., 2014; Williams \& Bizimis, 2014).

Oxygen isotopes have long been known as valuable tracers of magmatic and hydrothermal processes. While 

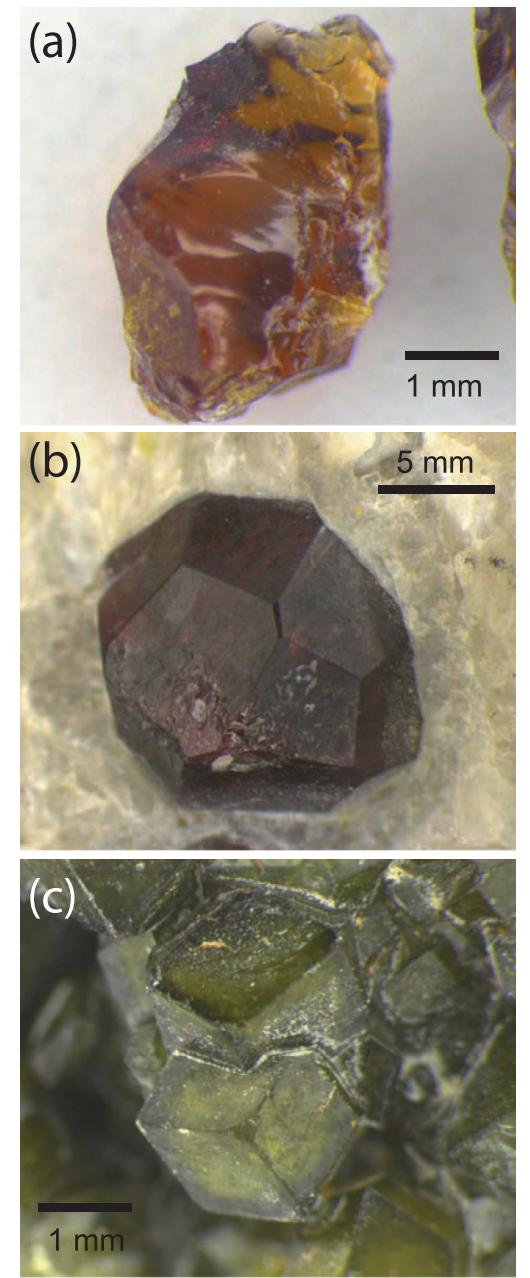

Fig. 1. Representative morphological features of the studied garnet crystals (binocular microphotographs) (a) xenocryst pyrope-rich garnet (Kakanui, New Zealand, KAK), (b) igneous almandine-rich garnet (Erongo, Namibia, ERO-R), (c) hydrothermal garnet (Erongo, Namibia, ERO-G).

bulk oxygen-isotope analysis of garnet has been performed for several decades (Valley et al., 1995), in situ measurements at the microscale have only become possible with modern ion microprobes (Vielzeuf et al., 2005; Martin et al., 2006, 2014; Page et al., 2010, 2014; Raimondo et al., 2012; Errico et al., 2013; Rubatto \& Angiboust, 2015). The capacity to analyze oxygen at the scale of chemical zoning is providing a new powerful tracer for studying the petrogenesis of garnet and the mobility of fluids in the crust and mantle. The analysis of garnet oxygen isotope composition by ion microprobe is affected by instrumental mass fractionation related to garnet composition. Therefore accurate measurements are heavily dependent on a series of garnet reference materials of different composition, particularly in grossular, spessartine and andradite component (Martin et al., 2006, 2014; Ickert et al., 2008; Page et al., 2010). Garnets that are homogeneous in major elements and oxygen isotope composition are in high demand.
Iron isotopes have long been applied to low-temperature rocks, mainly in relation to redox-related mass transfer of $\mathrm{Fe}$, often in association with the oxygenation of the atmosphere and biogeochemical processes (Beard et al., 1999, 2003; Rouxel et al., 2005; Dauphas \& Rouxel, 2006; Anbar \& Rouxel, 2007). With improving analytical techniques (Weyer \& Schwieters, 2003; Schoenberg \& von Blanckenburg, 2005; Dauphas \& Rouxel, 2006; Sossi et al., 2015) resolvable $\mathrm{Fe}$ isotope variations in hightemperature rocks and minerals have been identified (Poitrasson \& Freydier, 2005; Williams et al., 2005; Teng et al., 2008; Schuessler et al., 2009; Williams \& Bizimis, 2014; Konter et al., 2016; Sossi et al., 2016). To the best of our knowledge, to date there is only very limited $\mathrm{Fe}$ isotope data for garnet (Beard \& Johnson, 2004; Williams et al., 2009; Williams \& Bizimis, 2014).

In light of increasing precisions and rapidly evolving in situ techniques, it is crucial to test the natural variability of these isotopes in garnet, but also to search for suitable reference materials. Here we explore the $\mathrm{O}$ and $\mathrm{Fe}$ isotope compositions of three different types of garnet from different tectonic environments. The aim is to search for natural variations in these minerals within grains $(\mathrm{O}$ isotopes), and within populations (Fe isotopes). For $\mathrm{O}$ isotopes we use in situ techniques in search for variations that relate to different growth zones. For Fe, we use highprecision solution analyses in bulk grain populations for a first assessment of heterogeneity and absolute variations within populations and between different species of the garnet family that formed under different conditions. We show that natural variations in both, $\mathrm{O}$ and $\mathrm{Fe}$ isotope systematics can be resolved and may potentially be a powerful addition to garnet research. One of our studied samples, that are available in relatively large quantities, might further qualify as a reference material.

\section{Sample description}

\subsection{Pyrope-rich garnet (Kakanui, New Zealand; KAK)}

Fragments of garnet crystals (Fig. 1a) commonly occur in the Kakanui Mineral Breccia (KMB), a calcareous volcanoclastic deposit located near Kakanui that crops out in the coast of Otago (New Zealand). This location is well known for providing a suite of eclogitic, granulitic and ultramafic xenoliths together with large mineral fragments (i.e. xenocrysts) hosted in a volcanic groundmass (mela-nephelinite). First descriptions of the KMB and their exotic fragments date from beginning of the last century (Thomson, 1905). For a review of the origin of xenoliths and megacrysts fragments included in the KMB the reader is referred to Fulmer et al. (2010). Garnet occurs both as large fragments up to $12 \mathrm{~mm}$ in length (megacrysts) and also associated to amphibole and clinopyroxene in ultramafic nodules (garnet-pyroxenites). Garnet crystals used in this study are exclusively megacrysts that can be discriminated from the ones occurring in the nodules based on their higher $\mathrm{Mg} / \mathrm{Fe}$ ratio and by the lack 
of solid-state deformation features. Garnet megacrysts are closely related to the host mela-nephelinite and crystallized shortly before eruption (Merrill \& Wyllie, 1975; Fulmer et al., 2010), whereas garnet-bearing nodules record evidence of a long history of deformation and reequilibration at mantle conditions unrelated to the host magma. Their abundance, size and homogeneity make the pyrope-rich garnet megacrysts from the KMB excellent standard material for electron microprobe and traceelement analyses (Fulmer et al., 2010). In this work we evaluate the potential of Kakanui garnet as reference material for oxygen and iron isotopes.

\subsection{Almandine-spessartine rich garnet (Erongo Region, Namibia; ERO-R)}

Large $(5-10 \mathrm{~mm})$ euhedral garnet crystals are found in the high-grade metamorphic terrains and associated leucogranites from the Northern Central Zone of the Damara Fold Belt in NW Namibia. Garnet investigated in this study shows dodecahedron and trapezohedron forms (Fig. 1b) and occurs within a leucocratic granite consisting of quartz, K-feldspar, plagioclase and biotite. Euhedral morphologies and chemical composition (see below) indicate a magmatic origin for this garnet, similar to that described by Jung et al. (2001) in the Early Paleozoic garnet-bearing S-type granites from the Oetmoed locality $(40 \mathrm{~km}$ North of the Early Cretaceous igneous complex of Spitzkoppe) in the Damara Belt (NW Namibia). High ${ }^{87} \mathrm{Sr} /{ }^{86} \mathrm{Sr}$ ratios and high $\delta{ }^{18} \mathrm{O}$ values indicate that the moderately to strongly peraluminous granites from this locality were formed by anatexis of mid-crustal Proterozoic metapelites (Jung et al., 2001).

\subsection{Green andradite garnet (Erongo Region, Namibia; ERO-G)}

Demantoid garnet (gem quality variety of andradite, Adamo et al., 2011) occurs filling open veins in calcsilicate rocks and marbles of the Pan-African Damara Fold Belt in NW Namibia. Veins are associated to a contact metamorphic event related to the intrusion of the Early Cretaceous Erongo Complex (e.g. Trumbull et al., 2003). Based on its chemical composition, growth zoning (see below) and morphology the studied green andradite garnet most likely derives from the Green Dragon Mine near Tubussis (Koller et al., 2012) or Namgar mine (Adamo et al., 2011), although the exact provenance was unknown to the local provider. The Namibian andradite garnet crystals are associated with hydrothermal activity and serve here as a rare $\mathrm{Fe}^{3+}$ end-member and a counterpart to the omnipresent $\mathrm{Fe}^{2+}$ varieties. They show well-developed dodecahedron forms with distinctive darker rims (Fig. 1c) and a moderate anomalous birefringence typical of the grossular-andradite solid solution (i.e., grandite, Hofmeister et al., 1998; Shtukenberg et al., 2001). Optical microscopy and electron-backscattered images reveal sharp oscillatory zoning related to changes in the proportion of grossular and andradite contents. Oscillatory zonation patterns similar to the ones reported here are well known in grandite garnet and have been interpreted as a result of the immiscibility in the grandite system during precipitation from hydrothermal fluids (see Jamtveit, 1991; Jamtveit et al., 1995) or by changes in the fluid source (Ivanova et al., 1998).

\section{Analytical techniques}

Analyses of major elements in garnet (Table 1) were performed using a Cameca SX100 electron microprobe at the Research School of Earth Sciences (RSES), the Australian National University (ANU) with operating conditions of $15 \mathrm{kV}$ acceleration voltage, and $20 \mathrm{nA}$ beam current focused to $1 \mu \mathrm{m}$. Natural and synthetic minerals were used as standards. Multiple analyses of Roberts Victor kimberlite garnet (South Africa) indicate that analytical precision is better than $2 \%$ for all elements except for $\mathrm{Ti}(4 \%)$.

Trace element concentrations were determined by laser ablation inductively coupled plasma mass spectrometer (LA-ICP-MS) at RSES. This system consists of a Lambda Physik Complex 110 Excimer laser $(\lambda=193 \mathrm{~nm})$ and a custom built HelEx laser ablation cell coupled to a Varian820 quadrupole ICP-MS. A NIST 612 glass standard was used as external standard with $\mathrm{Al}$ obtained from electron microprobe analyses (EPMA) employed as the internal standard. All trace elements are reported relative to reference values for NIST-612 as listed in Jochum et al. (2011). The LA-ICP-MS analyses were performed using a laser pulse rate of $5 \mathrm{~Hz}$ and a spot size of $73 \mu \mathrm{m}$. Data reduction was performed with the Iolite 2.4 software (Hellstrom et al., 2008).

Garnet fragments from the three samples were mounted in a separate epoxy mount together with the UWG-2 (Valley et al., 1995) and andradite ANDRG (Martin et al., 2014) garnet standards for oxygen isotope measurements. The epoxy mount was then polished and coated with aluminium. Oxygen isotope measurements were performed using the SHRIMP II multi-collector ion microprobe at RSES (ANU) with a $\mathrm{Cs}^{+}$primary beam accelerated at $15 \mathrm{keV}$ with an intensity of $3.5 \mathrm{nA}$. The resulting beam spot was elliptical with an average size of $\sim 25 \times 20 \mu \mathrm{m}$, as measured on SEM images after the SHRIMP-II analysis. Details of the instrumental conditions can be found in Ickert et al. (2008) and Martin et al. (2014). Oxygen isotopes ratios $\left({ }^{18} \mathrm{O} /{ }^{16} \mathrm{O}\right)$ are presented as deviations $\left(\delta^{18} \mathrm{O}\right)$ from the Vienna standard mean ocean water (VSMOW). The UWG-2 garnet was used as primary standard $\left(\delta^{18} \mathrm{O} 5.8 \%\right.$, Valley et al., 1995) and reproduced over the analytical sessions with a standard deviation of $0.1-0.2 \%$; Kakanui garnet reproduced with a standard deviation of $0.15 \%$. Secondary standard ANDRG returned measured $\delta^{18} \mathrm{O}$ values, before matrix correction, of $11.24 \pm 0.14 \% \mathrm{o}(1 \sigma)$ in agreement with values reported by Martin et al. (2014; 10.9-11.2\%). To further test the homogeneity of Kakanui garnet, additional chips collected 
Table 1. Major element composition of garnet samples as determined by electron microprobe (wt $\%$ ). $\mathrm{H}_{2} \mathrm{O}^{+}$determined by FTIR.

\begin{tabular}{|c|c|c|c|c|c|c|c|c|}
\hline & \multicolumn{2}{|c|}{ KAK } & \multicolumn{2}{|c|}{ ERO-R } & \multicolumn{4}{|c|}{ ERO-G } \\
\hline $\mathrm{SiO}_{2}$ & 41.1 & $(0.4)$ & 36.5 & $(0.3)$ & 36.8 & $(0.7)$ & 35.6 & 38.8 \\
\hline $\mathrm{Al}_{2} \mathrm{O}_{3}$ & 23.5 & $(0.13)$ & 20.72 & $(0.17)$ & 6.05 & $(2.71)$ & 2.78 & 13.46 \\
\hline $\mathrm{Fe}_{2} \mathrm{O}_{3}{ }^{\text {calc }}$ & 0.08 & - & b.d.1. & - & 20.16 & - & 24.75 & 9.07 \\
\hline $\mathrm{FeO}^{\text {calc }}$ & 12.40 & $(0.13)$ & 29.15 & $(0.19)$ & 1.87 & $(3.28)$ & 1.40 & 3.10 \\
\hline $\mathrm{CaO}$ & 5.64 & $(0.04)$ & 0.52 & $(0.03)$ & 32.68 & $(0.33)$ & 31.99 & 33.57 \\
\hline $\mathrm{Na}_{2} \mathrm{O}$ & 0.03 & $(0.01)$ & 0.04 & $(0.01)$ & 0.01 & $(0.01)$ & b.d.l. & 0.02 \\
\hline $\mathrm{H}_{2} \mathrm{O}^{+}$ & & & & & 0.05 & & 0.01 & 0.08 \\
\hline Total & 100.4 & & 99.9 & & 98.0 & & 96.7 & 98.7 \\
\hline \multicolumn{9}{|c|}{ Cations per formula unit computed using GTcalc (Locock, 2008) } \\
\hline $\mathrm{Ti}$ & 0.030 & & - & & 0.006 & & 0.000 & 0.010 \\
\hline $\mathrm{Fe}^{3+}$ & 0.013 & & - & & 1.256 & & 1.587 & 0.541 \\
\hline $\mathrm{Fe}^{2+}$ & 0.739 & & 2.003 & & 0.137 & & 0.112 & 0.208 \\
\hline Mn & 0.018 & & 0.853 & & 0.021 & & 0.011 & 0.028 \\
\hline $\mathrm{Mg}$ & 1.795 & & 0.085 & & - & & 0.000 & 0.000 \\
\hline $\mathrm{Ca}$ & 0.436 & & 0.046 & & 2.914 & & 2.943 & 2.859 \\
\hline $\mathrm{Na}$ & 0.004 & & 0.006 & & 0.002 & & - & 0.003 \\
\hline $\mathrm{H}_{4}$ & 0.000 & & 0.000 & & 0.007 & & 0.012 & 0.001 \\
\hline Total & 8.000 & & 7.999 & & 8.000 & & 8.000 & 8.000 \\
\hline \multicolumn{9}{|c|}{ End-members (Locock, 2008) } \\
\hline Katoite & & & & & $0.2 \%$ & & $0.4 \%$ & $0.0 \%$ \\
\hline
\end{tabular}

b.d.l. below detection limit

in a second campaign were mounted in epoxy with UWG2 garnet standard, coated with $\mathrm{Au}$, and analysed in three sessions at the SwissSIMS laboratory at the University of Lausanne with a Cameca IMS 1280HR. Analytic conditions followed Seitz et al. (2017). A $10 \mathrm{kV} \mathrm{Cs}^{+}$ primary Gaussian beam was used with a $\sim 1.7-2.2 \mathrm{nA}$ current, resulting in a spot size of $\sim 15-20 \mu \mathrm{m}$. The UWG2 and Kakanui garnet reproduced over the analytical sessions with a standard deviation of $0.10-0.15 \%$.

Bulk oxygen-isotope compositions of Kakanui garnet were measured at the stable-isotope laboratory of the University of Lausanne (Switzerland) using the $\mathrm{CO}_{2}$ laser fluorination method as reported in Lacroix \& Vennemann (2015). Two analyses of $\sim 0.2 \mathrm{mg}$ were made on fragments of the same grain from the second collection campaign. The $\mathrm{O}_{2}$ was expanded into the dual inlet of a Thermo Finningan MAT 253 mass spectrometer. All results were corrected to the NBS-28 quartz $(9.64 \%$; Coplen et al., 1983 ) and expressed relative to VSMOW.
For bulk Fe isotope analyses, garnet fragments were handpicked under a microscope and $c a .3-6 \mathrm{mg}$ of garnet separates were first washed in milli-Q water in ultrasound. Separates were dissolved in a concentrated $\mathrm{HF}-\mathrm{HNO}_{3}$ acid mixture (1:5) in $3 \mathrm{ml}$ Savillex vials on a hotplate at $\sim 120{ }^{\circ} \mathrm{C}$ for $48 \mathrm{~h}$. After drying of all samples, the residues were re-dissolved in $8 \mathrm{M} \mathrm{HCl}$ and $\mathrm{Fe}$ was separated from the mineral matrices using chromatographic extraction resins. A detailed description of the procedure is listed in Cheng et al. (2014). Subsequent isotope analyses of purified Fe were performed on a Thermo-Fisher Neptune plus high-resolution multi-collector ICP-MS housed at the ANU. Details of the mass spectrometric setup, techniques and various standard reference materials to ensure international data comparison are listed in Sossi et al. (2015). In brief, all individual samples were adjusted in concentration relative to the standard, spiked with a natural Ni solution to correct for instrumental mass bias, and bracketed between the IRMM-014 standard reference 


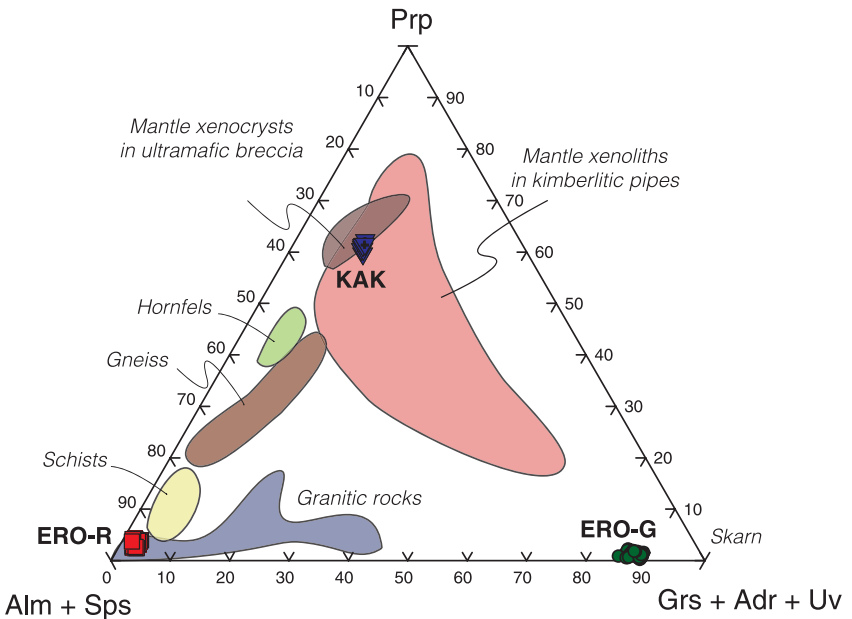

Fig. 2. Garnet major-element compositions expressed in terms of end-member fractions. Fields from Hofmeister et al. (1998).

material. All samples are reported in the delta notation relative to IRMM-014:

$\delta^{56,57} \mathrm{Fe}=\left(\frac{{ }^{56,57} \mathrm{Fe} /{ }^{54} \mathrm{Fe}_{\text {Sample }}}{{ }^{6,57} \mathrm{Fe} /{ }^{54} \mathrm{Fe}_{\text {IRMM }-014}}-1\right) \times 1000$

where ${ }^{56,57} \mathrm{Fe}$ relates to either ${ }^{56} \mathrm{Fe}$ or ${ }^{57} \mathrm{Fe}$. For all separates a mean value is given, which is the average of at least three replicate analyses of the same dissolution.

\section{Results and discussion}

\subsection{Major and trace element composition}

Major-element contents in garnet from the three studied samples obtained by EPMA are presented in Table 1 (average of $>8$ spot analyses). Calculated $\mathrm{Fe}_{2} \mathrm{O}_{3}$ based on stoichiometry and recast analyses of garnet into endmembers were computed with GTcalc (Locock, 2008) and are plotted in Fig. 2 following the classification diagram of Hofmeister et al. (1998). Garnet compositions fall in the field of mantle xenocrysts (KAK), granitic rocks (ERO-R) and skarn (ERO-G).

\subsubsection{KAK pyrope-rich garnet (Kakanui, New Zealand)}

The KAK garnet $\left(\mathrm{Alm}_{22-23} \operatorname{Prp}_{62-63} \mathrm{Grs}_{12} \mathrm{Adr}_{2} \mathrm{Sps}_{1}\right.$, mineral end-members abbreviations are after Whitney \& Evans 2010) shows a remarkable homogeneity in major elements with $1 \sigma$ typically below $0.2 \mathrm{wt} \%$ (except for $\mathrm{SiO}_{2}$ ) in agreement with Fulmer et al. (2010). Neither chemical zoning nor mineral inclusions were observed. KAK is furthermore characterized by highly uniform composition in trace elements (Table 2, Fig. 3, see also Zack et al., 1997, and Fulmer et al., 2010). Chondritenormalized rare earth element (REE) patterns (Fig. 3) for KAK show a smooth trend with depletion in light REE (LREE) toward $\mathrm{La}(0.1 \times \mathrm{C} 1$ chondrite) relative to heavy REE (HREE, $50 \times \mathrm{C} 1$ ). KAK shows relatively small and
Table 2. Average trace element compositions of garnet samples as determined by LA-ICP-MS (ppm).

\begin{tabular}{|c|c|c|c|c|c|c|}
\hline & \multicolumn{2}{|c|}{ Kakanui } & \multicolumn{2}{|c|}{ Erongo Red } & \multicolumn{2}{|c|}{ Erongo Green } \\
\hline & $n=11$ & $1 \sigma$ & $n=29$ & $1 \sigma$ & $n=42$ & $1 \sigma$ \\
\hline $\mathrm{Sc}$ & 89 & 2 & 277 & 58 & 1 & 0.3 \\
\hline $\mathrm{Ti}$ & 3402 & 58 & 208 & 73 & 850 & 429 \\
\hline V & 160 & 3 & 16 & 14 & 30 & 5 \\
\hline $\mathrm{Cr}$ & 52 & 2 & 9 & 9 & 2 & 2 \\
\hline $\mathrm{Co}$ & 64.5 & 0.6 & 6.5 & 0.6 & 0.07 & 0.03 \\
\hline $\mathrm{Ni}$ & 35.8 & 0.5 & 0.10 & 0.05 & 0.42 & 0.11 \\
\hline $\mathrm{Cu}$ & 1.0 & 0.1 & 0.11 & 0.04 & 0.07 & 0.04 \\
\hline $\mathrm{Zn}$ & 35.6 & 0.8 & 66.1 & 2.3 & 1.4 & 1.0 \\
\hline $\mathrm{Ga}$ & 8.1 & 0.2 & 23.6 & 3.1 & 10.8 & 4.9 \\
\hline $\mathrm{Rb}$ & 0.004 & 0.002 & 0.018 & 0.005 & 0.1 & 0.3 \\
\hline $\mathrm{Sr}$ & 0.32 & 0.01 & 0.02 & 0.01 & 0.1 & 0.2 \\
\hline $\mathrm{Y}$ & 65 & 1 & 347 & 69 & 61 & 15 \\
\hline $\mathrm{Zr}$ & 74 & 1 & 13 & 1 & 40 & 26 \\
\hline $\mathrm{Nb}$ & 0.08 & 0.01 & 0.07 & 0.07 & 6 & 1.9 \\
\hline Mo & 0.12 & 0.01 & 4.0 & 0.1 & 0.14 & 0.06 \\
\hline $\mathrm{Cd}$ & 0.11 & 0.03 & 0.48 & 0.09 & 0.11 & 0.08 \\
\hline In & 0.11 & 0.01 & 0.12 & 0.02 & 50 & 55 \\
\hline $\mathrm{Sn}$ & 0.32 & 0.01 & 0.41 & 0.10 & 3000 & 823 \\
\hline $\mathrm{Sb}$ & - & - & 0.01 & 0.01 & 0.03 & 0.04 \\
\hline Cs & - & - & - & - & 0.2 & 0.4 \\
\hline $\mathrm{Ba}$ & - & - & - & - & 0.1 & 0.2 \\
\hline $\mathrm{La}$ & 0.021 & 0.002 & - & - & 0.3 & 0.2 \\
\hline $\mathrm{Ce}$ & 0.268 & 0.007 & - & - & 3 & 2 \\
\hline $\operatorname{Pr}$ & 0.114 & 0.006 & - & - & 1.4 & 0.9 \\
\hline $\mathrm{Nd}$ & 1.44 & 0.05 & 0.04 & 0.01 & 15 & 9 \\
\hline $\mathrm{Sm}$ & 1.71 & 0.04 & 0.54 & 0.15 & 12 & 5 \\
\hline $\mathrm{Eu}$ & 1.00 & 0.03 & 0.010 & 0.003 & 2.4 & 1.1 \\
\hline $\mathrm{Gd}$ & 4.8 & 0.1 & 6 & 1 & 17.0 & 6.2 \\
\hline $\mathrm{Tb}$ & 1.15 & 0.02 & 4 & 1 & 2.5 & 0.8 \\
\hline Dy & 10.3 & 0.2 & 51 & 9 & 14 & 4 \\
\hline Но & 2.52 & 0.04 & 11 & 2 & 2.2 & 0.5 \\
\hline $\mathrm{Er}$ & 8.20 & 0.13 & 39 & 12 & 4.7 & 1.2 \\
\hline $\mathrm{Tm}$ & 1.21 & 0.02 & 8 & 3 & 0.5 & 0.1 \\
\hline $\mathrm{Yb}$ & 7.95 & 0.11 & 64 & 30 & 2.5 & 0.6 \\
\hline $\mathrm{Lu}$ & 1.16 & 0.02 & 8 & 5 & 0.3 & 0.1 \\
\hline Hf & 1.49 & 0.04 & 0.5 & 0.1 & 0.9 & 0.7 \\
\hline $\mathrm{Ta}$ & 0.01 & 0.00 & 0.1 & 0.1 & 0.4 & 0.3 \\
\hline W & 0.006 & 0.003 & 0.03 & 0.01 & 7 & 13 \\
\hline $\mathrm{Pb}$ & 0.020 & 0.001 & 0.001 & 0.001 & 0.3 & 0.6 \\
\hline $\mathrm{Bi}$ & 0.001 & 0.001 & 0.001 & 0.002 & 0.01 & 0.01 \\
\hline Th & 0.003 & 0.001 & - & - & 0.04 & 0.03 \\
\hline $\mathrm{U}$ & 0.006 & 0.001 & 0.05 & 0.02 & 0.03 & 0.02 \\
\hline
\end{tabular}

constant LREE-middle REE (MREE) and MREE-HREE fractionations $\quad\left(\mathrm{La} / \mathrm{Sm}_{\mathrm{N}}=0.01 ; \quad \mathrm{Sm} / \mathrm{Yb}_{\mathrm{N}}=0.22-0.25\right)$. KAK garnet lacks a Eu anomaly $\left(\mathrm{Eu}_{\mathrm{N}} / \mathrm{Eu}^{*} \approx 1, \mathrm{Eu}^{*}=\right.$ $\left.\left(\mathrm{Sm}_{\mathrm{N}}+\mathrm{Gd}_{\mathrm{N}}\right) / 2\right)$ and presents a negative $\mathrm{Sr}$ anomaly $\left(\mathrm{Sr}_{\mathrm{N}} /\right.$ $\left.\mathrm{Sr}^{*}<0.02, \mathrm{Sr}^{*}=\left(\operatorname{Pr}_{\mathrm{N}}+\mathrm{Nd}_{\mathrm{N}}\right) / 2\right)$.

\subsubsection{ERO-R almandine-spessartine rich garnet (Erongo Region, Namibia)}

The ERO-R ( $\left.\mathrm{Alm}_{62-65} \operatorname{Prp}_{6-7} \mathrm{Grs}_{0-1} \mathrm{Adr}_{0-1} \mathrm{Sps}_{27-29}\right)$ majorelement composition is homogeneous ( $1 \sigma$ below $0.2 \mathrm{wt} \%$, except for $\mathrm{SiO}_{2}$ ) with typically no major variations in chemical compositional along electron microprobe 

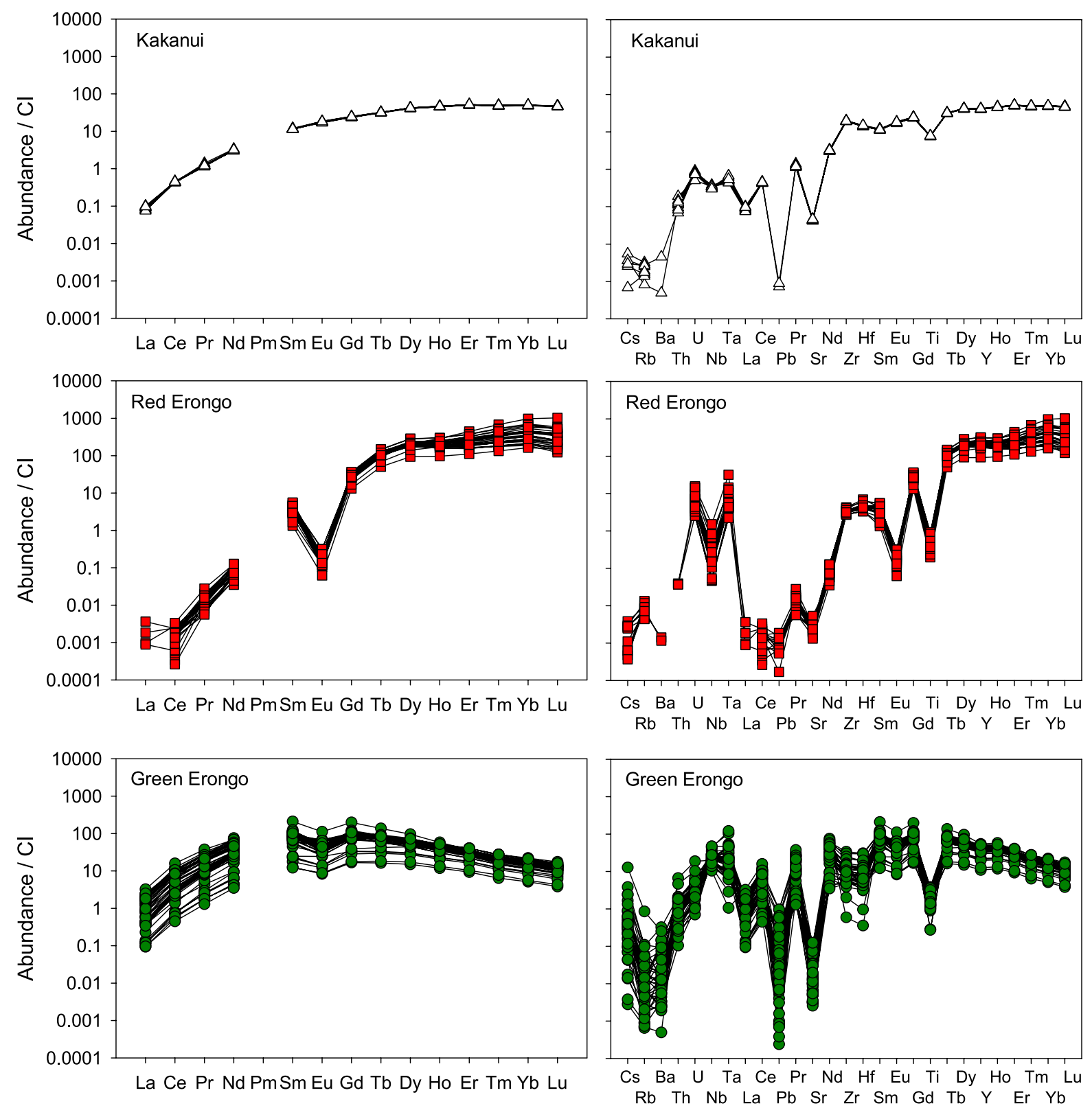

Fig. 3. Chondrite-normalized rare earth element concentrations (left) and trace element patterns (right) for KAK, ERO-R and ERO-G garnet (normalization to chondrite data of McDonough \& Sun, 1995). (Online version in colour.)

profiles. It is worth to note, however, that other garnet crystals from the same locality are slightly zoned in pyrope and spessartine components $(<0.5-1 \mathrm{wt} \%$ in $\mathrm{MgO}$ and $\mathrm{MnO}$, cf. Fig. 3 in Jung et al., 2001). Low $\mathrm{CaO}(<0.5 \mathrm{wt}$ $\%)$ and high $\mathrm{MnO}$ and $\mathrm{FeO}$ contents $(\sim 12$ and $\sim 29 \mathrm{wt} \%$, respectively) are typical of garnet crystallized from granitic melts under pressure conditions corresponding to the upper crust ( $<4 \mathrm{kbar}$, Clemens \& Wall, 1981; Jung et al., 2001; Zhang et al., 2012). ERO-R shows a steep normalized REE pattern (Fig. 3) with a strong depletion of LREE and enrichment of HREE (100-1000 x C1). It is characterized by a variable and very high LREE-MREE and MREE-HREE fractionation $\left(\mathrm{La} / \mathrm{Sm}_{\mathrm{N}}<0.001 ; \mathrm{Sm} /\right.$
$\left.\mathrm{Yb}_{\mathrm{N}}=0.002-0.026\right)$. A strong positive $\mathrm{Eu}$ anomaly is prominent $\left(\mathrm{Eu}_{\mathrm{N}} / \mathrm{Eu}^{*}=0.01-0.02\right)$ whereas the negative $\mathrm{Sr}$ anomaly is less pronounced $\left(\mathrm{Sr}_{\mathrm{N}} / \mathrm{Sr}^{*}=0.03-0.18\right)$.

\subsubsection{ERO-G green andradite garnet (Erongo Region, Namibia)}

The ERO-G garnet $\left(\mathrm{Grs}_{16-55} \mathrm{Adr}_{33-83} \mathrm{Sps}_{0-2}\right)$ shows a complex and a very heterogeneous composition spanning most of the binary grossular-andradite join. Calculated $\mathrm{Fe}_{2} \mathrm{O}_{3}$ (Locock, 2008) ranges from 9 to $24 \mathrm{wt} \%$. At least two different garnet growth stages can be distinguished based on the crosscutting pattern of the oscillatory zoning. 

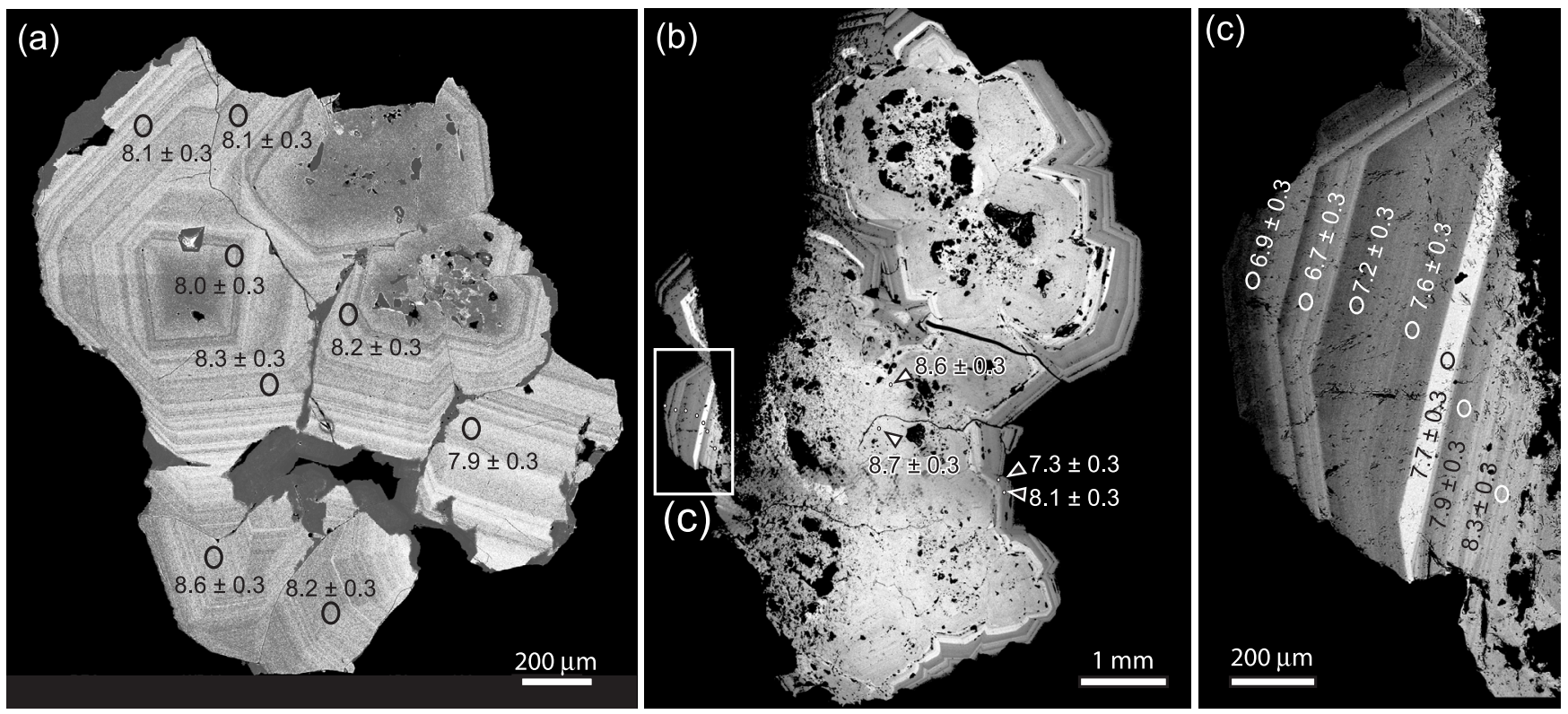

Fig. 4. Backscattered electron images of ERO-G showing complex oscillatory zoning. (a) Aggregate of garnet crystals dominated by the first stage of growth. (b) Aggregate of garnet crystals with porous cores and a well developed overgrowth. (c) A detail of the zoning pattern in the overgrowth enlarged from (b). Circles indicate the location of ion microprobe analyses and number are corrected $\delta^{18} \mathrm{O}$ values $(1 \sigma)$.

The first and volumetrically most important garnet type (ca. 80-90 vol\%) forms the garnet cores (Fig. 4a). The inner part of the cores typically shows abundant inclusions (up to $30 \mu \mathrm{m}$ in length) of quartz, calcite and wollastonite and large cavities (up to $500 \mu \mathrm{m}$ in length) presumably originally filled by fluids. Oscillatory zoning in the cores is rhythmic in cycles of $50-100 \mu \mathrm{m}$; the contacts of individual layers in each cycle are sharp and have a width of $1-3 \mu \mathrm{m}$. The second stage of garnet growth occurs along fractures or rims around the cores (Fig. $4 \mathrm{~b}$ and c). In most cases the transition between the two garnet growth stages is transitional but in other zones it is associated to a partial dissolution or resorption of the core. Backscattered-electron images reveal that the oscillatory pattern in the rim is characterized by alternating layers with larger compositional contrast than those occurring in the core (Fig. 4b). However, it is difficult to establish the precise change in terms of grossular-andradite component given the very fine structure of the oscillatory zoning. The cores are generally richer in andradite content $(60-70 \%$ in average, and up to $80 \%$, Table 1), whereas the outermost layers of the second growth stage are significantly richer in grossular (up to 60\%). Average and extreme compositions are presented in Table 1 .

Grossular-andradite rich garnet is known to contain variable amounts of structurally bounded $\mathrm{H}_{2} \mathrm{O}$ (in the form of hydroxyl $\mathrm{OH}^{-}$groups, Rossman \& Aines, 1986, 1991; Rossman, 1996; Amthauer \& Rossman, 1998; Shtukenberg et al., 2001; Adamo et al., 2011). FTIR measurements on double polished thick sections $(\sim 350 \mu \mathrm{m})$ were performed to confirm this expectation (Fig. 5). Similarly to major elements, water concentration is also heterogeneous, ranging from 0.01 to $0.08 \mathrm{wt} \% \mathrm{H}_{2} \mathrm{O}$ (using IR absorption coefficient from Rossman \& Aines, 1991), and correlates with the oscillatory zoning (Fig. 4b). Trace elements in
ERO-G are also extremely heterogeneous at the grain scale in accordance with the fine oscillatory zoning. Normalized REE pattern for ERO-G is characterized by a variable enrichment of MREE over HREE resulting in $\mathrm{Sm} / \mathrm{Yb}_{\mathrm{N}}$ ratios ranging from 1.3 to 13.1 . The LREE are extremely variable spanning more than two orders of magnitude (i.e. $\left.\mathrm{La}_{\mathrm{N}}=0.09-3.22\right)$. The LREE-MREE fractionation $(\mathrm{La} /$ $\left.\mathrm{Sm}_{\mathrm{N}}=0.002-0.028\right)$ in ERO-G is lower than for ERO-R.

\subsection{Oxygen isotopes}

\subsubsection{KAK pyrope-rich garnet}

The homogeneity of Kakanui garnet is confirmed by ion microprobe analysis using two instruments. Each ion microprobe session analysed different garnet chips, and yielded repeatability between 0.10 and $0.15 \%$ standard deviation (Fig. 6a, Table 3). When the Kakanui ion microprobe analyses are standardized against UWG-2 garnet, which has virtually the same grossular content $\left(\mathrm{Grs}_{12}\right.$ in Kakanui and $\mathrm{Grs}_{14}$ in UWG-2) but different almandine/pyrope ratio (Kakanui $\mathrm{X}_{\mathrm{Alm}} / \mathrm{X}_{\operatorname{Prp}}=0.4$ and UWG-2 $\left.\mathrm{X}_{\mathrm{Alm}} / \mathrm{X}_{\mathrm{Prp}}=1.1\right)$, the $\delta^{18} \mathrm{O}$ values are between 5.6 and $5.8 \%$ with one exception at 5.35\%. This would suggest that, unlike what was found for the grossular, spessartine and andradite component (Page et al., 2010; Martin et al., 2014), differences in Fe/Mg between garnet samples do not induce any bias in the measurement of oxygen isotopes by ion microprobe.

Bulk separate laser fluorination analyses returned an average $\delta^{18} \mathrm{O}$ value of $5.67 \pm 0.02 \%$ for the Kakanui garnet (Table 4). Notably, Gonzaga et al. (2010) reported a lower $\delta^{18} \mathrm{O}$ value of $5.22 \%$ for Kakanui garnet from the garnet pyroxenites, which is at the lower limit for garnet in oceanic garnet pyroxenites in that study (5.2-5.8\%). Gonzaga et al. (2010) also reported a 

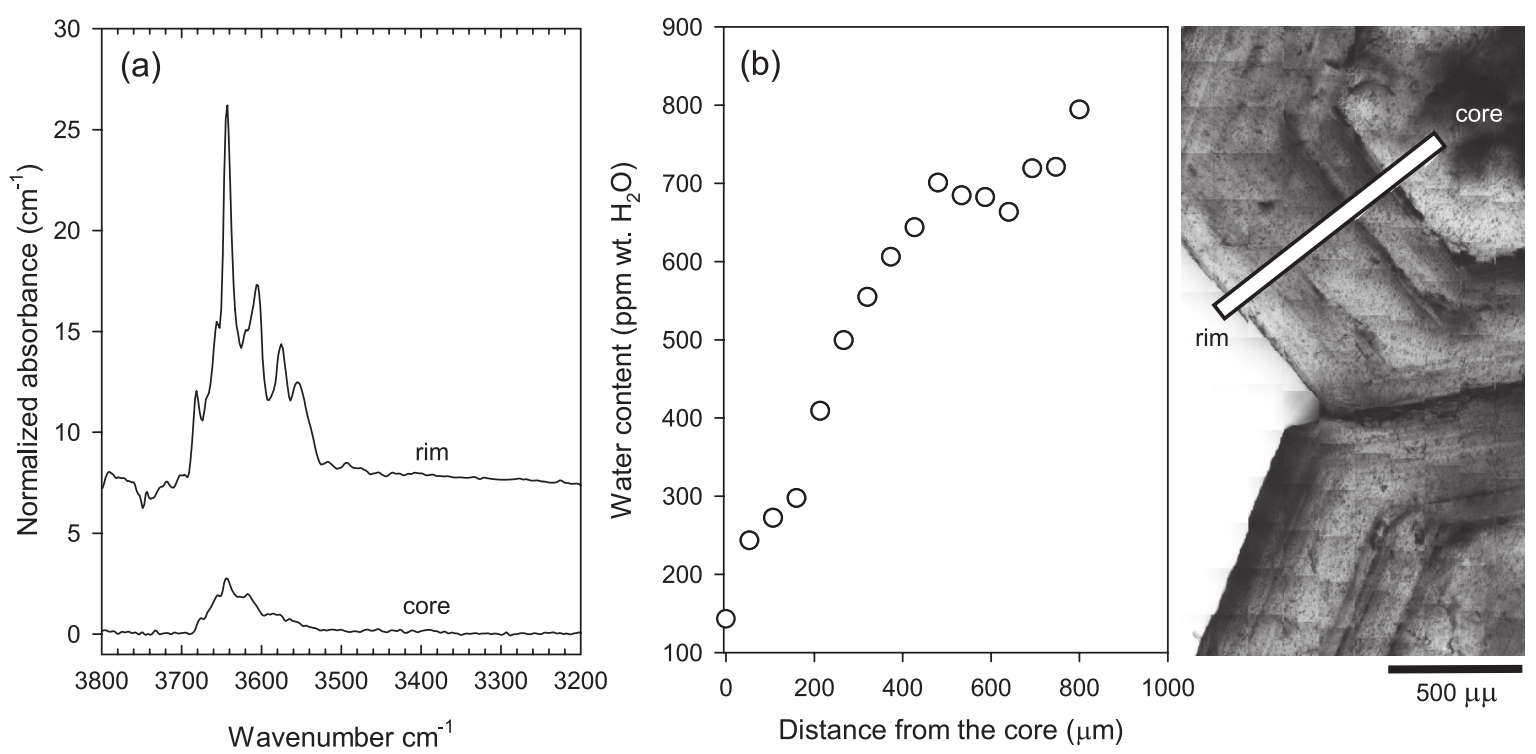

Fig. 5. (a) Representative IR normalized spectra for the core and the overgrowth in ERO-G showing the occurrence of structurally bounded hydroxyl groups. (b) Water content variation from core to rim (transect shown on the right).

negligible fractionation between garnet and clinopyroxene $\left(\Delta_{\mathrm{cpx} \text {-grt }}=+0.03 \%\right)$ from the garnet-pyroxenite nodules from Kakanui. Our laser fluorination data from the garnet megacrysts plot within the average range of bulk garnet peridotite isotope composition $(5.5 \pm 0.2 \%$ ) reported by Mattey et al. (1994).

The Kakanui outcrop exposes a calcareous volcanoclastic deposit composed of three distinct units (Dickey, 1968a, b). The mineral breccia contains two types of garnet; megacrysts (investigated in this study, $\delta^{18} \mathrm{O}=5.7 \%$ ) and garnet clinopyroxenite nodules (Gonzaga et al., 2010, $5.2 \%$ ). It is thus possible that the two garnet types from the Deborah Volcanic formation that include the KMB have slightly different oxygen isotope composition.

\subsubsection{ERO-R almandine-spessartine rich garnet}

The SHRIMP analysis of the Erongo red garnet returned $\delta^{18} \mathrm{O}$ values from 8.9 to $9.7 \%$ (average $9.3 \pm 0.3 \%, 1 \sigma, n=20$, Table 3 ) after matrix correction according to Martin et al. (2014). These values are higher than those found in magmatic garnet from peraluminous granitoids from South Mountain Batholith in southwestern Nova Scotia $(8.21 \pm 0.19 \%$; $n=10$, Lackey et al., 2011), but within that expected for crustal rocks. Jung et al. (2001) reported wholerock $\delta^{18} \mathrm{O}$ ranging from 13.8 to $15.1 \%$ in peraluminous granites with magmatic garnet from Oetmoed (Damara Belt, Namibia). Based on geochemical data, the origin of these granites was postulated to be melting of metasedimentary crustal rocks (Lackey et al., 2006). Significantly lower whole-rock $\delta^{18} \mathrm{O}$ (between 11.5 and $12.9 \%$ ) have been also reported in A-type granites from the same locality although these granites lack magmatic garnet (Jung et al., 1998).

\subsubsection{ERO-G green andradite garnet}

Three fragments each one consisting of a cluster of several garnet crystals were analysed for oxygen isotopes. Analyses in fragments 1 and 2 correspond to the first stage of growth (Fig. 4a, Table 3). Average $\delta^{18} \mathrm{O}$ values for these two fragments corrected for matrix, including a significant correction for the andradite component (Martin et al., 2014), are similar ( $8.3 \pm 0.3 \%, n=5 ; 8.2 \pm 0.3 \%$, $n=8$, Table 3 ). A profile analysed in fragment 3 covers the two garnet types: core and rim of one single garnet crystal (Fig. $4 b$ and c). Corrected values for the cores are similar to those for fragments 1 and 2 for a cumulative value of $8.6 \pm 0.3 \%$ o $(1 \sigma, n=3)$. The rim has an average $\delta^{18} \mathrm{O}$ value of $7.4 \pm 0.3 \%$ o $(1 \sigma, n=8$, Fig. $6 \mathrm{~b})$. Given the fine-scale nature of the oscillatory zoning compared to the spot size analysed by the ion microprobe (ca. $20 \times 25 \mu \mathrm{m}$, Fig. 4), matrix corrections are challenging for ERO-G. Core compositions used for matrix corrections correspond to the average of 42 core EMP analyses (Tables 1 and 3). Compositional layers in the overgrowths are wider and relatively homogeneous enabling a direct correction of each isotope analysis with the EMP data close to the analysis. However it is important to note that, in detail, the very finely layered structure in ERO-G is beyond the spatial resolution of the ion microprobe and possibly even electron microprobe. Although large uncertainties are introduced by the matrix correction $( \pm 0.3 \%)$, average $\delta^{18} \mathrm{O}$ values for the overgrowth $(7.4 \pm 0.3 \%)$ are lower than for the andradite-rich core $(8.3 \pm 0.3 \%)$. This apparent correlation between the oxidation state of iron (i.e. andradite component) and the oxygen isotope composition of the garnet would be in agreement with the laser fluorination data obtained with the thin saw blade technique by Clechenko \& Valley (2003) and confirmed with ion microprobe data by Page et al. (2010) 
(a) Kakanui garnet

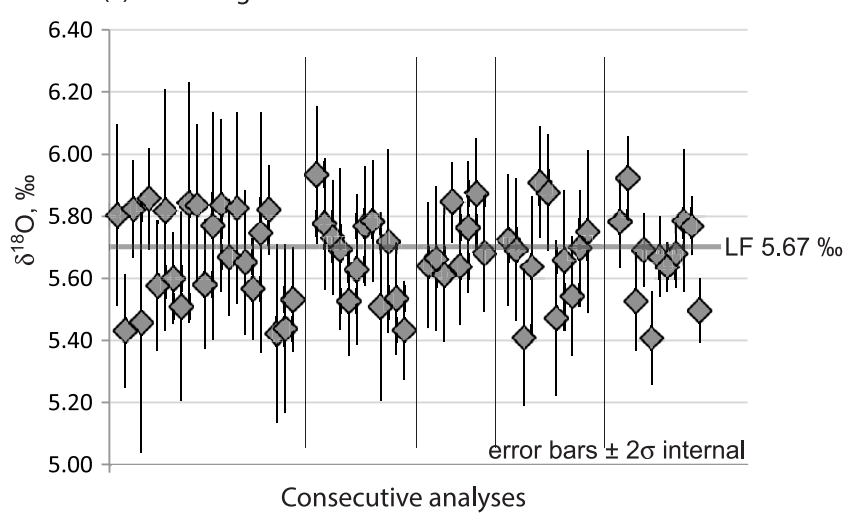

(b) Erongo green garnet

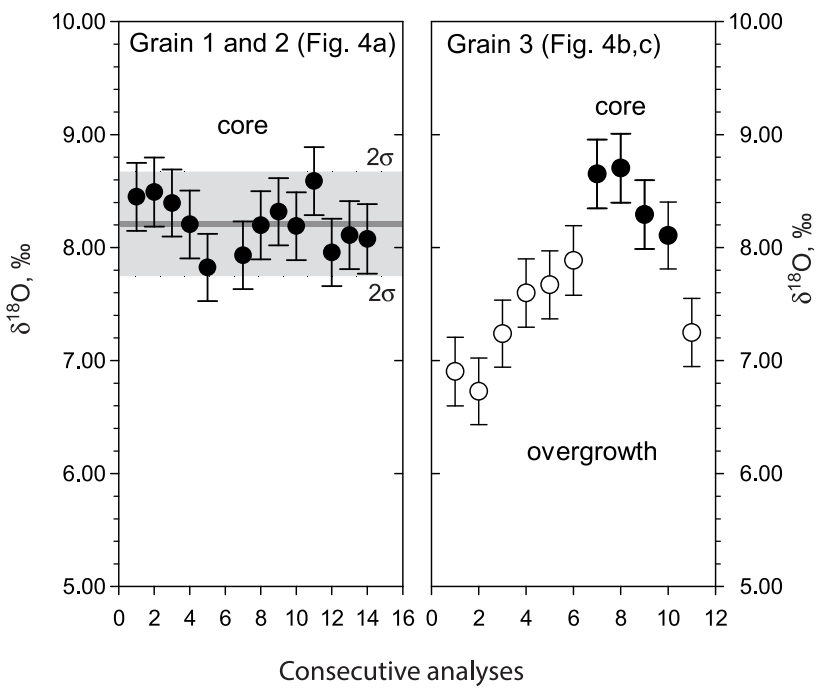

Fig. 6. (a) Repeatability of oxygen isotope analyses of Kakanui garnet by ion microprobe. Thin vertical lines divide the five sessions, each of them analyzing different chips of garnet. The thick horizontal line represents the laser fluorination reference value to which the analyses have been standardized. (b) $\delta^{18} \mathrm{O}$ values for two ERO-G garnet grains (Fig. $4 \mathrm{a}$ and $\mathrm{b}$, c respectively). $\delta^{18} \mathrm{O}$ values for the profile shown in Fig. 4b and c in ERO-G. Matrix correction for grossular, andradite and spessartine after Martin et al. (2014). The error on the average values includes the uncertainty of the matrix correction.

for garnets from the grossular-andradite join. A similar correlation between oxygen isotopes and andradite component in garnet was shown in the study of Crowe et al. (2001). However, the observed correlation in ERO$\mathrm{G}$ is significantly weaker (around $1 \%$ over a relative change in andradite component of $25 \%$ ) when compared to those previously described (e.g. around $7 \% \delta^{18} \mathrm{O}$ over $30 \%$ relative change of Adr, in Clechenko \& Valley, 2003). In the above mentioned previous studies the large variation in garnet $\delta^{18} \mathrm{O}$ was attributed to external fluid flow.

The oxygen isotope signature of ERO-G most likely represents the $\delta^{18} \mathrm{O}$ of the fluid involved in the formation of this hydrothermal garnet. An aqueous fluid in equilibrium with a garnet composition of $8.3-7.4 \%$ at a temperature of $650{ }^{\circ} \mathrm{C}$ assumed for the crystallization of the host granite has a $\delta^{18} \mathrm{O}$ of $\sim 10-11 \%$ (garnet-water fractionation factors from Zheng, 1993). Other hydrothermal garnet of similar origin show more extreme variations in $\delta^{18} \mathrm{O}$ in one single crystal $\left(-6 \% 0^{-}+5 \%\right)$ that have been interpreted in terms of a cyclic variability in the proportion of magmatic and meteoric fluids (Crowe et al., 2001; Clechenko \& Valley, 2003). This limited variation in $\delta^{18} \mathrm{O}$ can be simply explained with a $T$ variation of 100 $150^{\circ} \mathrm{C}$ between core and rim growth in a fluid of buffered oxygen isotopic composition, but cannot exclude the input of external fluids with slightly different oxygen isotopic compositions (see also $\mathrm{Fe}$ isotope variations).

\subsection{Iron isotopes}

\subsubsection{KAK pyrope-rich garnet}

Similar to the limited variation in major, trace elements and $\mathrm{O}$ isotope compositions, the $\mathrm{Fe}$ isotope values for five separates of the Kakanui garnet are identical within analytical uncertainty (Fig. 7a). The weighted average of $\delta^{57} \mathrm{Fe}$ values of the garnet fragments is $\delta^{57} \mathrm{Fe}=+0.09 \pm$ $0.01 \%$ (Fig. $7 b$, Table 5), which is resolvable above the depleted mantle value of $\delta^{57} \mathrm{Fe}=+0.05 \pm 0.01 \%$ o (Craddock et al., 2013; Sossi et al., 2015). The observed $\delta^{57} \mathrm{Fe}$ values $(0.07-0.10 \%$ ) fall within the range of reported values for garnet in garnet-pyroxenite from Hawaii (0.03-0.21\%, Williams \& Bizimis, 2014). The minor variations observed in the individual splits are within analytical uncertainty of the weighted average. This average is proposed here as the reference value for Kakanui garnet.

Whereas the $\mathrm{O}$ isotope composition is identical to the depleted mantle (Valley et al., 1998), the Fe isotope composition is distinctly heavier than bulk peridotitic mantle of ca. 0.05\% (Sossi et al., 2015). Oxygen isotope fractionation between peridotite and melt is minor, and in conjunction with melt-garnet equilibrium in radiogenic $\mathrm{Hf}$ isotopes (Fulmer et al., 2010), it is reasonable to assume that the garnet and alkaline melt are in $\mathrm{Fe}$ isotopic equilibrium. In addition, first principles suggest that $\mathrm{Fe}^{2+}$ in an VIII-fold $\mathrm{O}$ coordination in the garnet structure prefers light Fe isotopes (Young et al., 2015; Sossi \& O'Neill, 2017). Hence, mineral-melt fractionation cannot account for the heavy Fe isotope offset between garnet and mantle. Instead, the offset can be best explained by an isotopically heavy melt in equilibrium with or heavier than garnet, considering $\mathrm{D}^{57} \mathrm{Fe}_{\text {MELT-PYR }}>1$. Such an isotopically heavy alkaline melt is plausible, considering a preferential partitioning of $\mathrm{Fe}^{3+}$ during partial melting (Canil et al., 1996) and combined first-order isotope fractionation towards heavier $\mathrm{Fe}$ isotopes during partial mantle melting (Williams et al., 2005; Weyer \& Ionov 2007; Williams \& Bizimis, 2014). This value is in line with that of isotopically heavy ocean island lavas (e.g., Teng et al., 2013; Konter et al., 2016). The existence of such melts enriched in heavy iron isotopes has been already proposed to account for garnet-pyroxenites with a cumulate origin (Williams \& Bizimis, 2014). Combined, it is possible that both $\mathrm{Fe}-\mathrm{O}$ 
Table 3. Oxygen analyses of garnet measured by SHRIMP ion microprobe. The garnet composition and $\delta^{18} \mathrm{O}$ bias due to the grossular, spessartine and andradite component are also reported.

\begin{tabular}{|c|c|c|c|c|c|c|c|c|c|c|c|c|c|c|c|c|}
\hline Label & Fragment & Domain & ${ }^{18} \mathrm{O} /{ }^{16} \mathrm{O}$ & $\pm 95 \% \mathrm{cl}$ & $\begin{array}{l}\text { Measured } \\
\delta^{18} \mathrm{O} \% \text { o }\end{array}$ & $\pm 1 \sigma$ & $\mathrm{X}_{\mathrm{Grs}}$ & $X_{\operatorname{Prp}}$ & $\mathrm{X}_{\mathrm{Sps}}$ & $\mathrm{X}_{\mathrm{Alm}}$ & $\mathrm{X}_{\mathrm{Adr}}$ & BIAS Grs & BIAS Sps & BIAS Adr & $\begin{array}{l}\text { Corrected } \\
\delta^{18} \mathrm{O} \%\end{array}$ & $\pm 1 \sigma^{1}$ \\
\hline ERO-R30 & 1 & core & 0.002047 & $1.67 \mathrm{E}-07$ & 9.51 & 0.08 & 0.018 & 0.028 & 0.284 & 0.669 & 0.000 & -1.12 & 1.51 & 0.00 & 9.12 & 0.27 \\
\hline ERO-R31 & 1 & core & 0.002047 & $1.12 \mathrm{E}-07$ & 9.68 & 0.05 & 0.018 & 0.028 & 0.284 & 0.669 & 0.000 & -1.12 & 1.51 & 0.00 & 9.29 & 0.26 \\
\hline ERO-R32 & 1 & core & 0.002047 & $1.72 \mathrm{E}-07$ & 9.69 & 0.08 & 0.018 & 0.028 & 0.284 & 0.669 & 0.000 & -1.12 & 1.51 & 0.00 & 9.30 & 0.27 \\
\hline ERO-R33 & 1 & core & 0.002046 & $1.43 \mathrm{E}-07$ & 9.29 & 0.07 & 0.018 & 0.028 & 0.284 & 0.669 & 0.000 & -1.12 & 1.51 & 0.00 & 8.90 & 0.26 \\
\hline ERO-R35 & 1 & core & 0.002048 & $9.10 \mathrm{E}-08$ & 10.08 & 0.04 & 0.018 & 0.028 & 0.284 & 0.669 & 0.000 & -1.12 & 1.51 & 0.00 & 9.69 & 0.26 \\
\hline ERO-R36 & 1 & core & 0.002048 & $8.10 \mathrm{E}-08$ & 9.88 & 0.04 & 0.018 & 0.028 & 0.284 & 0.669 & 0.000 & -1.12 & 1.51 & 0.00 & 9.49 & 0.26 \\
\hline ERO-R37 & 2 & core & 0.002047 & $1.26 \mathrm{E}-07$ & 9.61 & 0.06 & 0.018 & 0.028 & 0.284 & 0.669 & 0.000 & -1.12 & 1.51 & 0.00 & 9.22 & 0.26 \\
\hline ERO-R38 & 2 & core & 0.002048 & $1.73 \mathrm{E}-07$ & 9.99 & 0.08 & 0.018 & 0.028 & 0.284 & 0.669 & 0.000 & -1.12 & 1.51 & 0.00 & 9.60 & 0.27 \\
\hline ERO-R39 & 2 & core & 0.002047 & $1.44 \mathrm{E}-07$ & 9.40 & 0.07 & 0.018 & 0.028 & 0.284 & 0.669 & 0.000 & -1.12 & 1.51 & 0.00 & 9.01 & 0.26 \\
\hline ERO-R40 & 2 & core & 0.002048 & $1.66 \mathrm{E}-07$ & 9.86 & 0.08 & 0.018 & 0.028 & 0.284 & 0.669 & 0.000 & -1.12 & 1.51 & 0.00 & 9.48 & 0.27 \\
\hline ERO-R41 & 2 & core & 0.002048 & $1.15 \mathrm{E}-07$ & 9.89 & 0.06 & 0.018 & 0.028 & 0.284 & 0.669 & 0.000 & -1.12 & 1.51 & 0.00 & 9.50 & 0.26 \\
\hline ERO-R42 & 2 & core & 0.002047 & $2.48 \mathrm{E}-07$ & 9.51 & 0.12 & 0.018 & 0.028 & 0.284 & 0.669 & 0.000 & -1.12 & 1.51 & 0.00 & 9.12 & 0.28 \\
\hline ERO-R43 & 2 & core & 0.002047 & $1.28 \mathrm{E}-07$ & 9.77 & 0.06 & 0.018 & 0.028 & 0.284 & 0.669 & 0.000 & -1.12 & 1.51 & 0.00 & 9.38 & 0.26 \\
\hline ERO-R44 & 3 & core & 0.002047 & $1.40 \mathrm{E}-07$ & 9.52 & 0.07 & 0.018 & 0.028 & 0.284 & 0.669 & 0.000 & -1.12 & 1.51 & 0.00 & 9.13 & 0.26 \\
\hline ERO-R45 & 3 & core & 0.002047 & $1.37 \mathrm{E}-07$ & 9.47 & 0.07 & 0.018 & 0.028 & 0.284 & 0.669 & 0.000 & -1.12 & 1.51 & 0.00 & 9.09 & 0.26 \\
\hline ERO-R46 & 4 & core & 0.002048 & $1.68 \mathrm{E}-07$ & 9.80 & 0.08 & 0.018 & 0.028 & 0.284 & 0.669 & 0.000 & -1.12 & 1.51 & 0.00 & 9.41 & 0.27 \\
\hline ERO-R47 & 4 & core & 0.002048 & $1.43 \mathrm{E}-07$ & 9.93 & 0.07 & 0.018 & 0.028 & 0.284 & 0.669 & 0.000 & -1.12 & 1.51 & 0.00 & 9.54 & 0.26 \\
\hline ERO-R48 & 4 & core & 0.002047 & $1.43 \mathrm{E}-07$ & 9.75 & 0.07 & 0.018 & 0.028 & 0.284 & 0.669 & 0.000 & -1.12 & 1.51 & 0.00 & 9.36 & 0.26 \\
\hline ERO-R49 & 4 & core & 0.002048 & $1.66 \mathrm{E}-07$ & 9.80 & 0.08 & 0.018 & 0.028 & 0.284 & 0.669 & 0.000 & -1.12 & 1.51 & 0.00 & 9.41 & 0.27 \\
\hline \multirow[t]{2}{*}{ ERO-R50 } & 4 & core & 0.002048 & $1.32 \mathrm{E}-07$ & 9.97 & 0.06 & 0.018 & 0.028 & 0.284 & 0.669 & 0.000 & -1.12 & 1.51 & 0.00 & 9.58 & 0.26 \\
\hline & & & & & & & & & & & & & average & $(n=20)$ & 9.33 & 0.26 \\
\hline ERO-G20 & 1 & core & 0.002057 & $1.35 \mathrm{E}-07$ & 14.54 & 0.07 & 0.292 & 0.000 & 0.007 & 0.020 & 0.681 & 1.32 & 0.00 & 4.77 & 8.45 & 0.30 \\
\hline ERO-G21 & 1 & core & 0.002057 & $1.77 \mathrm{E}-07$ & 14.58 & 0.09 & 0.292 & 0.000 & 0.007 & 0.020 & 0.681 & 1.32 & 0.00 & 4.77 & 8.49 & 0.31 \\
\hline ERO-G22 & 1 & core & 0.002057 & $9.20 \mathrm{E}-08$ & 14.48 & 0.04 & 0.292 & 0.000 & 0.007 & 0.020 & 0.681 & 1.32 & 0.00 & 4.77 & 8.40 & 0.30 \\
\hline ERO-G23 & 1 & core & 0.002057 & $1.26 \mathrm{E}-07$ & 14.29 & 0.06 & 0.292 & 0.000 & 0.007 & 0.020 & 0.681 & 1.32 & 0.00 & 4.77 & 8.20 & 0.30 \\
\hline \multirow[t]{2}{*}{ ERO-G24 } & 1 & core & 0.002056 & $9.10 \mathrm{E}-08$ & 13.91 & 0.04 & 0.292 & 0.000 & 0.007 & 0.020 & 0.681 & 1.32 & 0.00 & 4.77 & 7.82 & 0.30 \\
\hline & & & & & & & & & & & & & average & $(n=5)$ & 8.27 & 0.32 \\
\hline ERO-G25 & 2 & core & 0.002056 & $1.30 \mathrm{E}-07$ & 14.02 & 0.06 & 0.292 & 0.000 & 0.007 & 0.020 & 0.681 & 1.32 & 0.00 & 4.77 & 7.93 & 0.30 \\
\hline ERO-G26 & 2 & core & 0.002057 & $1.43 \mathrm{E}-07$ & 14.28 & 0.07 & 0.292 & 0.000 & 0.007 & 0.020 & 0.681 & 1.32 & 0.00 & 4.77 & 8.20 & 0.30 \\
\hline ERO-G27 & 2 & core & 0.002057 & $9.50 \mathrm{E}-08$ & 14.41 & 0.05 & 0.292 & 0.000 & 0.007 & 0.020 & 0.681 & 1.32 & 0.00 & 4.77 & 8.32 & 0.30 \\
\hline ERO-G28 & 2 & core & 0.002057 & $1.26 \mathrm{E}-07$ & 14.28 & 0.06 & 0.292 & 0.000 & 0.007 & 0.020 & 0.681 & 1.32 & 0.00 & 4.77 & 8.19 & 0.30 \\
\hline ERO-G29 & 2 & core & 0.002057 & $1.32 \mathrm{E}-07$ & 14.68 & 0.06 & 0.292 & 0.000 & 0.007 & 0.020 & 0.681 & 1.32 & 0.00 & 4.77 & 8.59 & 0.30 \\
\hline ERO-G30 & 2 & core & 0.002056 & $1.11 \mathrm{E}-07$ & 14.04 & 0.05 & 0.292 & 0.000 & 0.007 & 0.020 & 0.681 & 1.32 & 0.00 & 4.77 & 7.96 & 0.30 \\
\hline ERO-G31 & 2 & core & 0.002056 & $1.35 \mathrm{E}-07$ & 14.20 & 0.07 & 0.292 & 0.000 & 0.007 & 0.020 & 0.681 & 1.32 & 0.00 & 4.77 & 8.11 & 0.30 \\
\hline \multirow[t]{2}{*}{ ERO-G32 } & 2 & core & 0.002056 & $1.85 \mathrm{E}-07$ & 14.16 & 0.09 & 0.292 & 0.000 & 0.007 & 0.020 & 0.681 & 1.32 & 0.00 & 4.77 & 8.08 & 0.31 \\
\hline & & & & & & & & & & & & & average & $(n=8)$ & 8.17 & 0.31 \\
\hline ERO-G7 & 3 & core & 0.002054 & $1.42 \mathrm{E}-07$ & 14.50 & 0.07 & 0.131 & 0.000 & 0.004 & 0.013 & 0.853 & 0.05 & 0.00 & 6.56 & 7.89 & 0.31 \\
\hline ERO-G10 & 3 & core & 0.002054 & $1.74 \mathrm{E}-07$ & 14.62 & 0.08 & 0.346 & 0.000 & 0.008 & 0.011 & 0.635 & 1.63 & 0.00 & 4.33 & 8.65 & 0.30 \\
\hline ERO-G11 & 3 & core & 0.002055 & $1.46 \mathrm{E}-07$ & 14.94 & 0.07 & 0.222 & 0.000 & 0.004 & 0.030 & 0.745 & 0.83 & 0.00 & 5.41 & 8.70 & 0.30 \\
\hline \multirow[t]{2}{*}{ ERO-G12 } & 3 & core & 0.002054 & $1.48 \mathrm{E}-07$ & 14.53 & 0.07 & 0.252 & 0.000 & 0.004 & 0.021 & 0.723 & 1.05 & 0.00 & 5.19 & 8.29 & 0.30 \\
\hline & & & & & & & & & & & & & average & $(n=4)$ & 8.38 & 0.35 \\
\hline
\end{tabular}


Table 3. (continued).

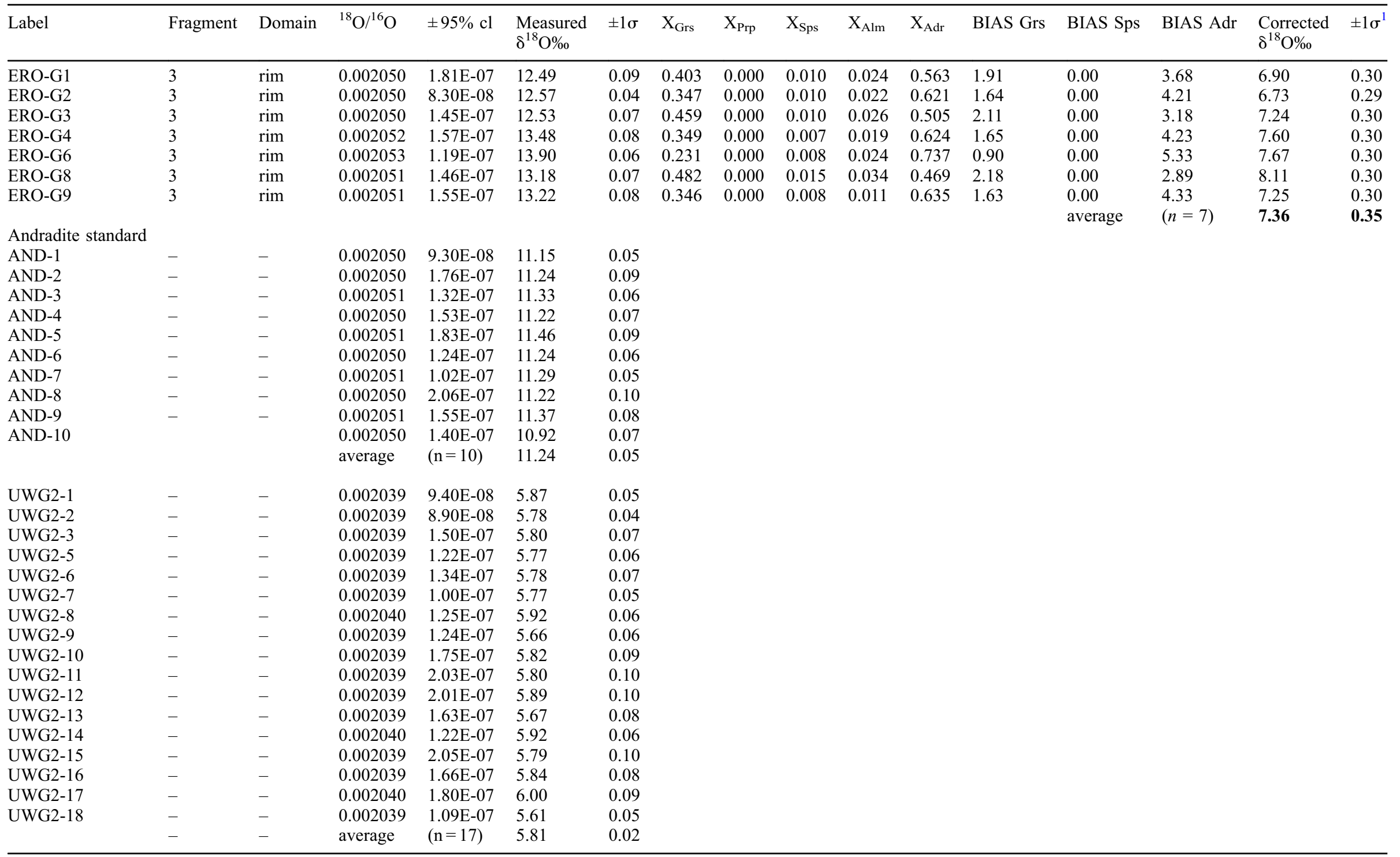

${ }^{1}$ The error includes the reproducibility of the standard UWG2 in the session and the residuals of the matrix bias correction 
Table 4. Oxygen isotope analyses of Kakanui garnet.

Bulk laser fluorination analyses

\begin{tabular}{lll}
\hline Label & weight, $\mathrm{mg}$ & $\delta^{18} \mathrm{O} \% \mathrm{o}$ \\
Kakanui Gt 35_4 & 1.80 & 5.68 \\
Kakanui Gt 35_5 & 1.50 & 5.66 \\
\hline
\end{tabular}

Ion microprobe analyses. Average value for each session standardised to $5.67 \%$ o based on laser fluorination analyses

\begin{tabular}{|c|c|c|}
\hline Label & $\delta^{18} \mathrm{O} \%$ & $\pm 1 \mathrm{~s}$ internal \\
\hline \multicolumn{3}{|l|}{ SHRIMP, ANU } \\
\hline KAKA-1 & 5.78 & 0.07 \\
\hline KAKA-2 & 5.92 & 0.07 \\
\hline KAKA-3 & 5.53 & 0.08 \\
\hline KAKA-4 & 5.69 & 0.06 \\
\hline KAKA-5 & 5.41 & 0.08 \\
\hline KAKA-6 & 5.67 & 0.07 \\
\hline KAKA-12 & 5.64 & 0.04 \\
\hline KAKA-13 & 5.68 & 0.05 \\
\hline KAKA-14 & 5.79 & 0.11 \\
\hline KAKA-15 & 5.77 & 0.05 \\
\hline KAKA-16 & 5.50 & 0.05 \\
\hline standard deviation & 0.15 & \\
\hline \multicolumn{3}{|c|}{ Cameca IMF 1280HR, UNIL } \\
\hline KAKA@1 & 5.80 & 0.15 \\
\hline KAKA@2 & 5.43 & 0.09 \\
\hline KAKA@3 & 5.82 & 0.08 \\
\hline KAKA@4 & 5.46 & 0.21 \\
\hline KAKA@5 & 5.86 & 0.08 \\
\hline KAKA@6 & 5.58 & 0.10 \\
\hline KAKA@7 & 5.82 & 0.19 \\
\hline KAKA@8 & 5.60 & 0.07 \\
\hline KAKA@9 & 5.51 & 0.15 \\
\hline KAKA@11 & 5.84 & 0.19 \\
\hline KAKA@12 & 5.84 & 0.13 \\
\hline KAKA@13 & 5.58 & 0.10 \\
\hline KAKA@14 & 5.77 & 0.18 \\
\hline KAKA@15 & 5.84 & 0.14 \\
\hline KAKA@16 & 5.67 & 0.09 \\
\hline KAKA@17 & 5.83 & 0.15 \\
\hline KAKA@18 & 5.65 & 0.12 \\
\hline KAKA@19 & 5.57 & 0.08 \\
\hline KAKA@20 & 5.75 & 0.19 \\
\hline KAKA@21 & 5.79 & 0.07 \\
\hline KAKA@22 & 5.39 & 0.14 \\
\hline KAKA@23 & 5.41 & 0.14 \\
\hline KAKA@24 & 5.50 & 0.08 \\
\hline standard deviation & 0.16 & \\
\hline
\end{tabular}

isotopes are heavier than the mantle. Although barely resolvable, this highlights the potential of high-precision analysis of the isotope pair, which, with appropriate statistics, could identify even smaller isotopic variations.

\subsubsection{ERO-R almandine-spessartine rich garnet}

The $\mathrm{Fe}$ isotope compositions of the red Erongo garnet splits show large variations. Although five splits of the garnet yield consistent values with a mean isotope
Table 4. (continued).

Ion microprobe analyses. Average value for each session standardised to $5.67 \%$ based on laser fluorination analyses

\begin{tabular}{|c|c|c|}
\hline KAKA@1 & 5.93 & 0.11 \\
\hline KAKA@2 & 5.78 & 0.11 \\
\hline KAKA@3 & 5.73 & 0.09 \\
\hline KAKA@4 & 5.69 & 0.13 \\
\hline KAKA@5 & 5.53 & 0.09 \\
\hline KAKA@6 & 5.63 & 0.12 \\
\hline KAKA@7 & 5.77 & 0.10 \\
\hline KAKA@8 & 5.78 & 0.10 \\
\hline KAKA@9 & 5.51 & 0.15 \\
\hline KAKA@10 & 5.72 & 0.15 \\
\hline KAKA@11 & 5.53 & 0.09 \\
\hline KAKA@12 & 5.43 & 0.08 \\
\hline standard deviation & 0.15 & \\
\hline KAK@1 & 5.64 & 0.10 \\
\hline KAK@2 & 5.66 & 0.12 \\
\hline KAK@3 & 5.61 & 0.11 \\
\hline KAK@4 & 5.85 & 0.06 \\
\hline KAK@5 & 5.64 & 0.09 \\
\hline KAK@7 & 5.76 & 0.11 \\
\hline KAK@8 & 5.87 & 0.09 \\
\hline KAK@9 & 5.68 & 0.10 \\
\hline standard deviation & 0.10 & \\
\hline KAK@10B & 5.72 & 0.11 \\
\hline KAK@11 & 5.69 & 0.11 \\
\hline KAK@12 & 5.41 & 0.11 \\
\hline KAK@13 & 5.64 & 0.11 \\
\hline KAK@14 & 5.91 & 0.09 \\
\hline KAK@15 & 5.88 & 0.09 \\
\hline KAK@16 & 5.47 & 0.13 \\
\hline KAK@17 & 5.66 & 0.11 \\
\hline KAK@18 & 5.54 & 0.10 \\
\hline KAK@19 & 5.70 & 0.09 \\
\hline KAK@20 & 5.75 & 0.13 \\
\hline standard deviation & 0.15 & \\
\hline
\end{tabular}

composition of $\delta^{57} \mathrm{Fe}=+0.09 \pm 0.05 \%$, two outliers deviate substantially from this value with a heavy and a light value, respectively (Fig. 7a). These variations in $\mathrm{Fe}$ isotopes are clearly resolvable with current high-precision techniques but also with the reproducibility for in situ analyses using laser ablation (ca. $\pm 0.1- \pm 0.2 \delta^{57} \mathrm{Fe}$ units, cf. Oeser et al., 2014). The red Erongo garnet is therefore not suitable as a standard reference material. The true nature and extent of $\mathrm{Fe}$ isotope variations in ERO-R garnet may be elucidated on a scale smaller than the splits used for the solution analyses. Irrespective of the reason, however, this demonstrates $\mathrm{Fe}-\mathrm{O}$ isotope decoupling and that different processes can possibly be traced by combined isotope analyses. The absolute variations further indicate the complexity of Fe isotope systematics during crustal anatexis, with extends those of bulk granitic systems (Foden et al., 2015) to negative values. 
Table 5. Iron isotope composition of garnet separates reported in the delta notation relative to the IRMM-014 standard reference material. Garnet series 'ERO-R' relates to red Erongo garnets (almandinespessartine), 'ERO-G' to green Erongo garnet (andradite) and 'KAK' to Kakanui garnet (pyrope). Each measurement represents the mean of three or more repetitive analyses of the same dissolution batch. Reported errors are calculated from the combined repeated analyses.

\begin{tabular}{lrrrrl}
\hline Sample & $\delta^{56} \mathrm{Fe}$ & $\pm 1 \sigma$ & $\delta^{57} \mathrm{Fe}$ & $\pm 1 \sigma$ & $\delta^{56} \mathrm{Fe} / \delta^{57} \mathrm{Fe}$ \\
\hline ERO-R1 & 0.08 & 0.01 & 0.13 & 0.02 & 0.560 \\
ERO-R2 & 0.07 & 0.02 & 0.12 & 0.03 & 0.618 \\
ERO-R3 & 0.06 & 0.03 & 0.08 & 0.02 & 0.761 \\
ERO-R4 & 0.04 & 0.02 & 0.08 & 0.02 & 0.507 \\
ERO-R5 & 0.20 & 0.00 & 0.28 & 0.01 & 0.702 \\
ERO-R6 & 0.05 & 0.01 & 0.07 & 0.01 & 0.631 \\
ERO-R7 & -0.13 & 0.02 & -0.14 & 0.01 & 0.942 \\
average & 0.05 & 0.04 & 0.09 & 0.05 & 0.674 \\
& & & & & \\
ERO-G1 & 0.52 & 0.04 & 0.70 & 0.02 & 0.749 \\
ERO-G2 & 0.41 & 0.02 & 0.60 & 0.01 & 0.686 \\
ERO-G3 & 0.60 & 0.00 & 0.90 & 0.01 & 0.662 \\
ERO-G4 & 0.71 & 0.02 & 1.07 & 0.01 & 0.660 \\
ERO-G5 & 0.54 & 0.01 & 0.91 & 0.03 & 0.593 \\
ERO-G6 & 0.21 & 0.01 & 0.37 & 0.01 & 0.553 \\
ERO-G7 & 0.51 & 0.01 & 0.83 & 0.03 & 0.618 \\
average & 0.50 & 0.06 & 0.77 & 0.09 & 0.646 \\
KAK-1 & 0.04 & 0.01 & 0.09 & 0.02 & 0.408 \\
KAK-2 & 0.05 & 0.02 & 0.10 & 0.02 & 0.484 \\
KAK-3 & 0.03 & 0.03 & 0.08 & 0.02 & 0.437 \\
KAK-4 & 0.07 & 0.03 & 0.10 & 0.03 & 0.736 \\
KAK-5 & 0.03 & 0.01 & 0.07 & 0.02 & 0.469 \\
average & 0.04 & 0.01 & 0.09 & 0.01 & 0.507 \\
\hline
\end{tabular}

\subsubsection{ERO-G green andradite garnet}

The Fe isotopes in splits of the andradite garnet are heavy compared to the other garnet, but broadly coincide with evolved crustal igneous rocks in general (e.g., Foden et al., 2015), yet show large internal variability. The positive $\mathrm{Fe}$ isotope signatures (on average, Fig. 7a) are interpreted here as a direct reflection of the structurally bound $\mathrm{Fe}^{3+}$ on the octahedrally coordinated site in the andradite crystal lattice. The variability and overall spread between the individual analyses, coupled with the major-element variability, however, point to a relation between $\mathrm{Fe}$ isotope composition and fluid composition from which the garnet formed. This strongly suggests that hydrothermal garnet has large $\mathrm{Fe}$ isotope variability in the respective growth zones (Fig. 7a), in line with zoning in major and trace element chemistry, and some variability in oxygen isotopes. This Fe isotope variation can clearly be resolved with current in situ Fe isotope analyses; despite disqualified as a standard reference material, it highlights the strong potential for $\mathrm{Fe}$ isotopes in future studies of crustal (hydrothermal) garnet genesis.
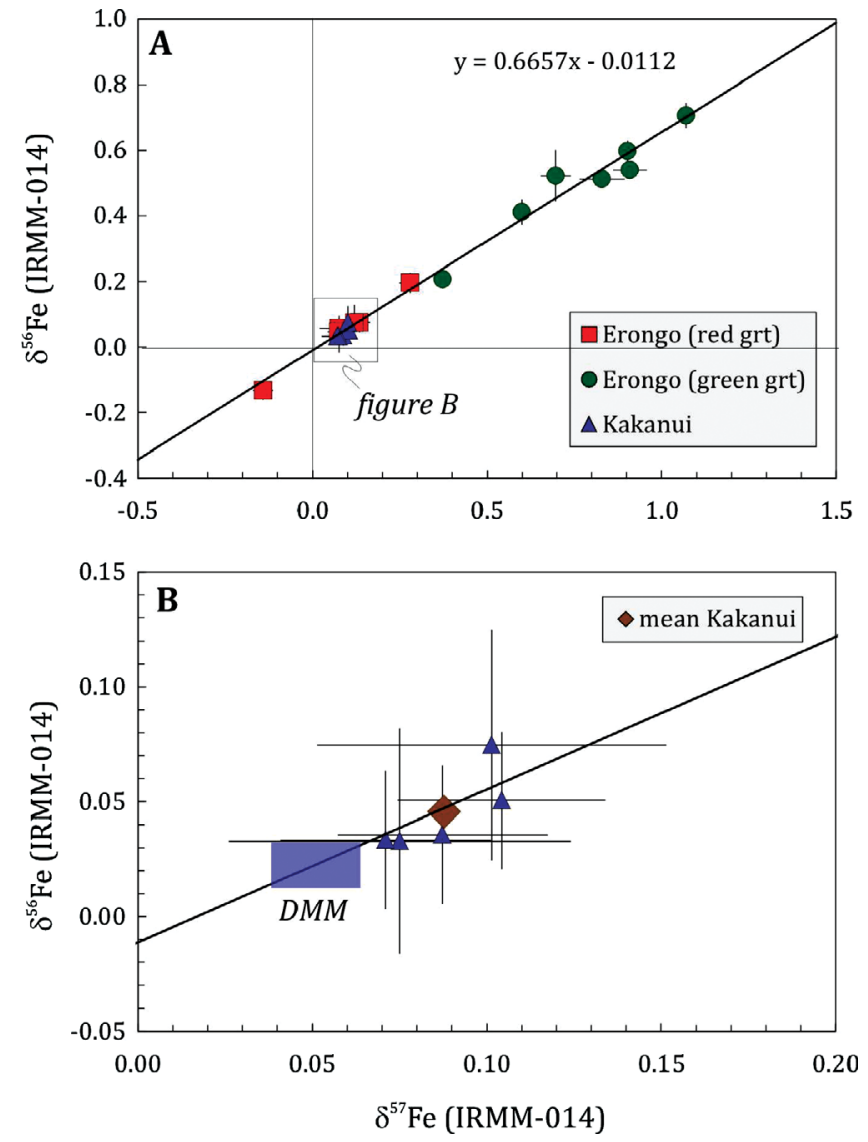

Fig. 7. (a) Fe isotope signatures (expressed in the delta notations) of the garnets analysed in this study, showing the relative values and absolute offset to the mantle (after Sossi et al., 2015), (b) inset.

\section{Implications}

Fluid/melt-rock interaction can results in different stable isotopes signatures. The decoupling between oxygen and iron isotopes in terms of homogeneity in garnet opens new possibilities to explore combined analyses as a petrogenetic tracer in the crust and mantle. However, further work is required to fully explore this proxy for the large variety of conditions under which garnet forms, especially in light of in situ $\mathrm{Fe}$ isotope analyses, which to date are still limited. A prerequisite for further advancement in $\mathrm{Fe}$ and stable isotope analysis is the assessment of new standards.

Our study show that the two igneous garnet samples investigated in this study are homogeneous for oxygen isotopes at the microscale, and thus qualify as reference materials for ion microprobe analysis. Kakanui pyrope-rich garnet is similar in grossular content to the well-established Gore Mountain garnet standard (UWG-2, Valley et al., 1995) $\left(\mathrm{Grs}_{12}\right.$ in Kakanui and Grs 14 in UWG-2), but notably differs in almandine-pyrope component $\left(\mathrm{Alm}_{22-23} \operatorname{Prp}_{62-63}\right.$ and $\mathrm{Alm}_{45} \operatorname{Prp}_{40}$, respectively). This makes Kakanui an 
important reference material in the analyses of grossularpoor, pyrope-rich garnets as for example found in mantle xenoliths. Erongo red garnet contains intermediate amount of $\mathrm{Mn}\left(\mathrm{Sps}_{27-29}\right)$, a composition that was previously missing in spessartine garnets proposed as ion-microprobe reference materials for oxygen isotopes (Page et al., 2010; Martin et al., 2014) and that bridges between spessartinepoor and spessartine-rich samples (e.g. garnet 2B3 with $\mathrm{Sps}_{4}$ and SpeBH with $\mathrm{Sps}_{68}$, Martin et al., 2014). This composition is particularly important for the oxygen analysis of metamorphic prograde garnet that is relatively rich in $\mathrm{Mn}$.

In Fe isotopes, only Kakanui garnet shows no resolvable isotope variations, whereas both Erongo garnet samples show variations outside analytical precision of our bulk analyses and that should also be resolvable with current in situ techniques (Oeser et al., 2014). Concerning joint $\mathrm{Fe}-\mathrm{O}$ isotope analyses, Kakanui qualifies as a reference material and we suggest a value of $\delta^{57} \mathrm{Fe}=+0.09 \pm 0.01 \%$ and $\delta^{18} \mathrm{O}=5.67 \pm 0.02 \%$ as reference values.

The variations in iron isotopes in garnet offer a promising prospect as a new tracer for investigating past redox conditions or the nature of the medium from which the garnet formed, i.e., an isotopically heavy $v$ s. light fluid or melt. However, it must be noted that $\mathrm{Fe}$ isotopes do not directly translate into a specific oxygen fugacity. In the crust, $\mathrm{Fe}$ transport in fluids is commonly associated with $\mathrm{Cl}$, which may impose additional fractionation through complexation and Fe loss during transport. In the mantle, preferential $\mathrm{Fe}^{2+}$ incorporation into garnet relates to light Fe isotopes, whereas metasomatic silicate melts, irrespective of redox condition, should a priori contain heavier isotopes, inherited from prior partial melting. In addition, $\mathrm{Fe}$ isotope variations in garnet may be accompanied by first-order isotope fractionation during incorporation of either ferric or ferrous $\mathrm{Fe}$ into the crystal lattice. Whilst this implies a disconnection of Fe isotopes and absolute oxygen fugacity, it highlights the potential to trace $\mathrm{Fe}$ mobility in fluids and other metasomatic agents.

Acknowledgements: The authors thank the associate editor, reviewer M. Bizimis and an anonymous reviewer for constructive comments. ON and DR acknowledge the financial support of the Australian Research Council (FT140101062 and DP1101015). This study benefited from the technical support of R. Rapp for electron microprobe analysis and L. Kinsley for LA-ICP-MS analysis. Benita Putlitz has kindly performed the laser fluorination analyses. Anne-Sophie Bouvier, Alice Vho and Lukas Baumgartner are thanked for support with the ion microprobe oxygen analyses in Lausanne.

\section{References}

Adamo, I., Gatta, G.D., Rotiroti, N., Diella, V., Pavese, A. (2011): Green andradite stones: gemmological and mineralogical characterisation. Eur. J. Mineral., 23, 91-100.
Amthauer, G. \& Rossman, G.R. (1998): The hydrous component in andradite garnet. Am. Mineral., 83, 835-840.

Anbar, A.D. \& Rouxel, O. (2007): Metal stable isotopes in paleoceanography. Annu. Rev. Earth Planet. Sci., 35, 717-746.

Beard, B.L. \& Johnson, C.M. (2004): Inter-mineral Fe isotope variations in mantle-derived rocks and implications for the $\mathrm{Fe}$ geochemical cycle. Geochim. Cosmochim. Acta, 68, 47274743.

Beard, B.L., Johnson, C.M., Cox, L., Sun, H., Nealson, K.H., Aguilar, C. (1999): Iron isotope biosignatures, Science, 285, 1889-1892.

Beard, B.L., Johnson, C.M., Skulan, J.L., Nealson, K.H., Cox, L., Sun, H. (2003): Application of $\mathrm{Fe}$ isotopes to tracing the geochemical and biological cycling of Fe. Chem. Geol., 195, 87-117.

Caddick, M.J. \& Kohn, M.J. (2013): Garnet: Witness to the Evolution of Destructive Plate Boundaries. Elements, 9, 427432.

Canil, D. \& O’Neill, H. St.C. (1996): Distribution of ferric iron in some upper-mantle assemblages. J. Petrol., 37, 609-635

Cheng, T., Nebel, O., Sossi, P.A., Chen, F. (2014): Refined separation of combined Fe-Hf from rock matrices for isotope analyses using AG-MP-1M and Ln-Spec chromatographic extraction resins. Methods $X, 1,144-150$.

Clechenko, C.C. \& Valley, J.W. (2003): Oscillatory zoning in garnet from the Willsboro Wollastonite Skarn, Adirondack Mts, New York: a record of shallow hydrothermal processes preserved in a granulite facies terrane. J. Metamorphic Geol., 21, 771-784.

Clemens, J.D. \& Wall, V.J. (1981):. Origin and crystallization of some peraluminous (S-type) granitic magmas. Can. Mineral., 19, 111-131.

Coplen, T.B., Kendall, C., Hopple, J., (1983): Comparison of stable isotope reference samples. Nature, 302, 236-238.

Craddock, P.R., Warren, J.M., Dauphas, N. (2013): Abyssal peridotites reveal the near-chondritic Fe isotopic composition of the Earth. Earth Planet. Sci. Lett., 365, 63-76.

Crowe, D.E., Riciputi, L.R., Bezenek, S., Ignatiev, A. (2001): Oxygen isotope and trace element zoning in hydrothermal garnets: Windows into large-scale fluid-flow behavior. Geology, 29, 479-482.

Dauphas, N. \& Rouxel, O. (2006): Mass spectrometry and natural variations of iron isotopes. Mass Spectrom. Rev., 25, 515550.

Dickey, J.S. Jr. (1968a): Eclogitic and other inclusions in the mineral breccia member of the Deborah volcanic formation at Kakanui, New Zealand. Am. Mineral., 53, 1304-1319.

- (1968b): Observations on the Deborah Volcanic Formation Near Kakanui, New Zealand. N. Z. J. Geol. Geophys. 11, 1159-1162. DOI:10.1080/00288306.1968.10420244.

Dragovic, B., Baxter, E.F., Caddick, M.J. (2015): Pulsed dehydration and garnet growth during subduction revealed by zoned garnet geochronology and thermodynamic modeling, Sifnos, Greece. Earth Planet. Sci. Lett., 413, 111-122.

Errico, J.C., Barnes, J.D., Strickland, A., Valley, J.W. (2013): Oxygen isotope zoning in garnets from Franciscan eclogite blocks: evidence for rock-buffered fluid interaction in the mantle wedge. Contrib. Mineral. Petrol., 166, 1161-1176.

Foden, J., Sossi, P.A., Wawryk, C.M. (2015): Fe isotopes and the contrasting petrogenesis of A-, I-, and S-type granites. Lithos, 212-215, 32-44. 
Fulmer, E.C., Nebel, O., van Westrenen, W. (2010): High-precision high field strength element partitioning between garnet, amphibole and alkaline melt from Kakanui, New Zealand. Geochim. Cosmochim. Acta, 74, 2741-2759.

Gonzaga, R.G., Lowry, D., Jacob, D.E., LeRoex, A., Schulze, D., Menzies, M.A. (2010): Eclogites and garnet pyroxenites: Similarities and differences. J. Volcanol. Geotherm. Res., 190, 235-247.

Hellstrom, C., Paton, C., Woodhead, J., Hergt, J. (2008): Iolite: Software for spatially resolved LA-(quad and MC) ICP-MS analysis. Mineral. Ass. Can. short course ser., 40, 343-348.

Hermann, J. \& Rubatto, D. (2003): Relating zircon and monazite domains to garnet growth zones: age and duration of granulite facies metamorphism in the Val Malenco lower crust. $J$. Metamorphic Geol., 21, 833-852.

Herwartz, D., Nagel, T.J., Muenker, C., Scherer, E.E., Froitzheim, N. (2011): Tracing two orogenic cycles in one eclogite sample by Lu-Hf garnet chronometry. Nat. Geosci., 4, 178-183.

Hofmeister, A.M., Schaal, R.B., Campbell, K.R., Berry, S.L., Fagan, T.J. (1998): Prevalence and origin of birefringence in 48 garnets from the pyrope-almandine-grossularite-spessartine quaternary. Am. Mineral., 83, 1293-1301.

Ickert, R.B., Hiess, J., Williams, I.S., Holden, P., Ireland, T.R., Lanc, P., Schram, N., Foster, J.J., Clement, S.W. (2008): Determining high precision, in situ, oxygen isotope ratios with a SHRIMP II: Analyses of MPI-DING silicate-glass reference materials and zircon from contrasting granites. Chem. Geol., 257, 114-128.

Ivanova, T.I., Shtukenberg, A.G., Punin, Y.O., Frank-Kamenetskaya, O.V., Sokolov, P.B. (1998): On the complex zonality in grandite garnets and implications. Mineral. Mag., 62, 857-868.

Jamtveit, B. (1991): Oscillatory zonation patterns in hydrothermal grossular-andradite garnet: Nonlinear dynamics in regions of immiscibility. Am. Mineral., 76, 1319-1327.

Jamtveit, B., Ragnarsdottir K.V., Wood B.J. (1995): On the origin of zoned grossular-andradite garnets in hydrothermal systems. Eur. J. Mineral., 7, 1399-1410.

Jochum, K.P., Weis, U., Stoll, B., Kuzmin, D., Yang, Q., Raczek, I., Jacob, D.E., Stracke, A., Birbaum, K., Frick, D.A., Günter, D., Enzweiler, J. (2011): Determination of reference values for NIST SRM 610-617 glasses following ISO guidelines. Geostand. Geoanal. Res., 35, 397-429.

Jung, S., Mezger, K., Hoernes, S. (1998): Petrology and geochemistry of syn- to post-collisional metaluminous A-type granites - a major and trace element and $\mathrm{Nd}-\mathrm{Sr}-\mathrm{Pb}-\mathrm{O}$-isotope study from the Proterozoic Damara Belt, Namibia. Lithos, 45, 147-175.

- , - - (2001): Trace element and isotopic ( $\mathrm{Sr}, \mathrm{Nd}, \mathrm{Pb}, \mathrm{O})$ arguments for a mid-crustal origin of Pan-African garnetbearing S-type granites from the Damara orogen (Namibia). Precambrian Res., 110, 325-355.

Koller, F., Pintér, Z., Szabó, C. (2012): The Demantoid garnets of the Green Dragon mine (Tubussi, Erongo Region, Namibia). Eur. Mineral. Conf., 1, EMC2012-313.

Konter, J.G., Pietruszka, A.J., Hanan, B.B., Finlayson, V.A., Craddock, P.R., Jackson, M.G., Dauphas, N. (2016): Unusual $\delta^{56} \mathrm{Fe}$ values in Samoan rejuvenated lavas generated in the mantle. Earth Planet. Sci. Lett., 450, 221-232.

Lackey, J.S., Erdmann, S., Hark, J.S., Nowak, R.M., Murray, K.E., Clarke, D.B., Valley, J.W. (2011):Tracing garnet origins in granitoid rocks by oxygen isotope analysis: examples from the south mountain batholith, Nova Scotia. Can. Mineral., 49, 417-439.
Lackey, J.S., Valley, J.W., Hinke, H.J. (2006): Deciphering the source and contamination history of peraluminous magmas using $\delta^{18} \mathrm{O}$ of accessory minerals: Examples from garnetbearing plutons of the Sierra Nevada batholith. Contrib. Mineral. Petrol., 151, 20-44.

Lacroix, B. \& Vennemann, T. (2015): Empirical calibration of the oxygen isotope fractionation between quartz and $\mathrm{Fe}-\mathrm{Mg}-$ chlorite. Geochim. Cosmochim. Acta, 149, 21-31.

Locock, A.J. (2008): An Excel spreadsheet to recast analyses of garnet into endmember components, and a synopsis of the crystal chemistry of natural silicate garnets. Comput. Geosci., 34, 1769-1780.

Martin, L., Duchêne, S., Deloule, E., Vanderhaeghe, O. (2006): The isotopic composition of zircon and garnet: a record of the metamorphic history of Naxos (Greece). Lithos, 87, 174-192.

Martin, L.A.J., Rubatto, D., Crépisson, C., Hermann, J., Putlitz, B., Vitale-Brovarone, A. (2014): Garnet oxygen analysis by SHRIMP-SI: Matrix corrections and application to highpressure metasomatic rocks from Alpine Corsica. Chem. Geol., 374-375, 25-36.

Mattey, D., Lowry, D., Macpherson, C. (1994): Oxygen isotope composition of mantle peridotite. Earth Planet. Sci. Lett., 128, 231-241.

McDonough, W.F. \& Sun, S.-S. (1995): The composition of the Earth. Chem. Geol. 120, 223-253. DOI:10.1016/0009-2541(94) 00140-4.

Merrill, R.B. \& Wyllie, P.J. (1975): Kaersutite and kaersutite eclogite from Kakanui, New Zealand: Water-excess and water-deficient melting to 30 kbars. Geol. Soc. Am. Bull., 86, 555-570.

Oeser, M., Weyer, S., Horn, I., Schuth, S. (2014): High-precision Fe and $\mathrm{Mg}$ isotope ratios of silicate reference glasses determined in situ by femtosecond LA-MC-ICP-MS and by solution nebulisation MC-ICP-MS. Geostand. Geoanal. Res., 38, 311-328.

Page, F.Z., Kita, N.T., Valley, J.W. (2010): Ion microprobe analysis of oxygen isotopes in garnets of complex chemistry. Chem. Geol., 270, 9-19.

Page, F.Z., Essene, E.J., Mukasa, S.B., Valley, J.W. (2014): A garnet-zircon oxygen isotope record of subduction and exhumation fluids from the Franciscan Complex, California. J. Petrol., 55, 103-131.

Poitrasson, F. \& Freydier, R. (2005): Heavy iron isotope composition of granites determined by high resolution MCICP-MS. Chem. Geol., 222, 132-147.

Pollington, A.D. \& Baxter, E.F. (2011): High precision microsampling and preparation of zoned garnet porphyroblasts for Sm-Nd geochronology. Chem. Geol., 281, 270-282.

Raimondo, T., Clark, C., Hand, M., Cliff, J., Harris, C. (2012): Highresolution geochemical record of fluid-rock interaction in a midcrustal shear zone: a comparative study of major element and oxygen isotope transport in garnet. J. Metamorphic Geol., 30, 255-280.

Raimondo, T., Payne, J., Wade, B., Lanari, P., Clark, C., Hand, M. (2017): Trace element mapping by LA-ICP-MS: assessing geochemical mobility in garnet. Contrib. Mineral. Petrol., 172, 17.

Rossman, G.R. (1996): Studies of OH in nominally anhydrous minerals. Phys. Chem. Minerals., 23, 299-304.

Rossman, G.R. \& Aines, R.D. (1986): Spectroscopy of a birefringent grossular from Asbestos, Quebec, Can. Am. Mineral., 71, 779-780.

-, - (1991): The hydrous components in garnets; grossularhydrogrossular. Am. Mineral., 76, 1153-1164. 
Rouxel, O.J., Bekker, A., Edwards, K.J. (2005): Iron isotope constraints on the Archean and Paleoproterozoic ocean redox state. Science., 307, 1088-1091.

Rubatto, D. \& Angiboust, S. (2015): Oxygen isotope record of oceanic and high-pressure metasomatism: a $P$-T-time-fluid path for the Monviso eclogites (Italy). Contrib. Mineral. Petrol., 170, $1-16$.

Schmidt, A., Pourteau, A., Candan, O., Oberhänsli, R. (2015): LuHf geochronology on cm-sized garnets using microsampling: new constraints on garnet growth rates and duration of metamorphism during continental collision (Menderes Massif, Turkey). Earth Planet. Sci. Lett., 432, 24-35.

Schoenberg, R. \& von Blanckenburg, F. (2005): An assessment of the accuracy of stable $\mathrm{Fe}$ isotope ratio measurements on samples with organic and inorganic matrices by high-resolution multicollector ICP-MS. Int. J. Mass Spectrom., 242, 257-272.

Schuessler, J.A., Schoenberg, R., Sigmarsson, O. (2009): Iron and lithium isotope systematics of the Hekla volcano, Iceland Evidence for $\mathrm{Fe}$ isotope fractionation during magma differentiation. Chem. Geol., 258, 78-91.

Seitz, S., Baumgartner, L.P., Bouvier, A.-S., Putlitz, B., Vennemann, T. (2017): Quartz Reference Materials for Oxygen Isotope Analysis by SIMS. Geostand. Geoanal. Res., 41, 69-75.

Shtukenberg, A.G., Punin, Y.O., Frank-Kamenetskaya, O.V., Kovalev, O.G., Sokolov, P.B. (2001): On the origin of anomalous birefringence in grandite garnets. Mineral. Mag., 65, 445-459.

Snyder, G.A., Taylor, L.A., Jerde, E.A., Clayton, R.N., Mayeda, T. K., Deines, P., Rossman, G.R., Sobolev, N.V. (1995): Archean mantle heterogeneity and the origin of diamondiferous eclogites, Siberia - Evidence from stable isotopes and hydroxyl in garnet. Am. Mineral., 80, 799-809.

Sossi, P.A. \& O'Neill, H.S.C. (2017): The effect of bonding environment on iron isotope fractionation between minerals at high temperature. Geochim. Cosmochim. Acta, 196, 121-143.

Sossi, P.A., Halverson, G.P., Nebel, O., Eggins, S.M. (2015): Combined separation of $\mathrm{Cu}, \mathrm{Fe}$ and $\mathrm{Zn}$ from rock matrices and improved analytical protocols for stable isotope determination. Geostand. Geoanal. Res., 39, 129-149.

Sossi, P.A., Nebel, O., Foden, J. (2016): Iron isotope systematics in planetary reservoirs. Earth Planet. Sci. Lett., 452, 295-308.

Spear, F.S. (2014): The duration of near-peak metamorphism from diffusion modelling of garnet zoning. J. Metamorphic Geol., 32, 903-914.

Teng, F.-Z., Dauphas, N., Helz, R.T. (2008): Iron isotope fractionation during magmatic differentiation in Kilauea Iki Lava Lake. Science, 320, 1620-1622.

Teng, F.-Z., Dauphas, N., Huang, S., Marty, B. (2013): Iron isotopic systematics of oceanic basalts. Geochim. Cosmochim. Acta, 107, 12-26.

Thomson, J.A. (1905): The gem gravels of Kakanui, with remarks on the geology of the district. Trans. proc. New Zealand Inst., 38, 482-495.

Trumbull, R.B., Bühn, B., Romer, R.L., Volker, F. (2003): The petrology of basanite-tephrite intrusions in the Erongo complex and implications for a plume origin of cretaceous alkaline complexes in Namibia. J. Petrol., 44, 93-112.
Valley, J.W., Kitchen, N., Kohn, M.J., Niendorf, C.R., Spicuzza, M. J. (1995): UWG-2, a garnet standard for oxygen isotope ratios: Strategies for high precision and accuracy with laser heating. Geochim. Cosmochim. Acta, 59, 5223-5231.

Valley, J.W., Kinny, P.D., Schulze, D.J., Spicuzza, M.J. (1998): Zircon megacrysts from kimberlite: oxygen isotope variability among mantle melts. Contrib. Mineral. Petrol., 133, 1-11.

Vielzeuf, D., Veschambre, M., Brunet, F. (2005): Oxygen isotope heterogeneities and diffusion profile in composite metamorphicmagmatic garnets from the Pyrenees. Am. Mineral., 90, 463472.

Weyer, S. \& Ionov, D.A. (2007): Partial melting and melt percolation in the mantle: The message from $\mathrm{Fe}$ isotopes. Earth Planet. Sci. Lett., 259, 119-133.

Weyer, S. \& Schwieters, J. (2003): High precision Fe isotope measurements with high mass resolution MC-ICPMS. Int. J. Mass Spectrom., 226, 355-368.

Whitney, D.L. \& Evans, B.W. (2010): Abbreviations for names of rock-forming minerals. Am. Mineral., 95, 185-187.

Williams, H.M. \& Bizimis, M. (2014): Iron isotope tracing of mantle heterogeneity within the source regions of oceanic basalts. Earth Planet. Sci. Lett. 404, 396-407.

Williams, H.M., Peslier, A.H., McCammon, C., Halliday, A.N., Levasseur, S., Teutsch, N., Burg, J.P. (2005): Systematic iron isotope variations in mantle rocks and minerals: The effects of partial melting and oxygen fugacity. Earth Planet. Sci. Lett., 235, 435-452.

Williams, H.M., Nielsen, S.G., Renac, C., Griffin, W.L., O’Reilly, S. Y., McCammon, C.A., Pearson, N., Viljoen, F., Alt, J.C., Halliday, A.N. (2009): Fractionation of oxygen and iron isotopes by partial melting processes: implications for the interpretation of stable isotope signatures in mafic rocks. Earth Planet. Sci. Lett., 283, 156-166.

Young, E.D., Manning, C.E., Schauble, E.A., Shahar, A., Macris, C.A., Lazar, C., Jordan, M. (2015): High-temperature equilibrium isotope fractionation of non-traditional stable isotopes: Experiments, theory, and applications. Chem. Geol., 395, 176-195.

Zack, T., Foley, S.F., Jenner, G.A. (1997): A consistent partition coefficient set for clinopyroxene, amphibole and garnet from laser ablation microprobe analysis of garnet pyroxenites from Kakanui, New Zealand. N. Jb. Mineral. Abh., 172, 23-41.

Zhang, J., Ma, C., She, Z. (2012): An early Cretaceous garnetbearing metaluminous A-type granite intrusion in the East Qinling Orogen, central China: Petrological, mineralogical and geochemical constraints. Geoscience Frontiers, 3, 635646.

Zheng, Y.F. (1993): Calculation of oxygen isotope fractionation in anhydrous silicate minerals. Geochim. Cosmochim. Acta, 57, 1079-1091.

Received 12 June 2017

Modified version received 4 December 2017

Accepted 10 December 2017 